\title{
Diurnal Variability of Lower and Middle Atmospheric Water Vapour Over The Asian Summer Monsoon Region: First Results From COSMIC-1 and TIMED- SABER Measurements
}

\section{Siddarth Shankar Das ( $\nabla$ dassiddhu@yahoo.com )}

Space Physics Laboratory, Vikram Sarabhai Space Centre https://orcid.org/0000-0002-6973-2774

K N Uma

Space Physics Laboratory, VSSC

K V Suneeth

India Meteorological Department

\section{Research Article}

Keywords: Diurnal variability, Water vapour, COSMIC-1, TIMED-SABER

Posted Date: August 17th, 2021

DOl: https://doi.org/10.21203/rs.3.rs-693267/v1

License: (9) This work is licensed under a Creative Commons Attribution 4.0 International License.

Read Full License

Version of Record: A version of this preprint was published at Climate Dynamics on April 22nd, 2022. See the published version at https://doi.org/10.1007/s00382-022-06282-5. 
2 Monsoon region: First results from COSMIC-1 and TIMED-SABER measurements

3 Siddarth Shankar Das ${ }^{1 *}$, K. N. Uma ${ }^{1}$ and K. V. Suneeth ${ }^{2}$

$4 \quad{ }^{1}$ Space Physics Laboratory, Vikram Sarabhai Space Centre, ISRO, Trivandrum-695022, India

$5 \quad{ }^{2}$ Numerical Weather Prediction Division, India Meteorological Department, MoES, New Delhi-

$6 \quad 110003$

$7 \quad *$ e-mail : siddarth_das@vssc.gov.in \& dassiddhu@yahoo.com

Abstract. First observations on the vertical structure of diurnal variability of tropospheric water vapour in the lower and middle atmosphere using 13 years of COSMIC and 18 years of SABER observations are presented in this paper. The most significant and new observation is that the middle stratospheric water vapour (SWV) enhancement is observed between 9-18 LT, whereas it is between 6-15 LT near tropopause in all the seasons. The diurnal amplitude of water vapour near tropopause is between 0.3-0.4 ppmv. Bimodal peaks are found in the diurnal amplitude of

15 SWV, maximizing between $25-30 \mathrm{~km}(\sim 0.4 \mathrm{ppmv})$ and $45-50 \mathrm{~km}(\sim 0.6 \mathrm{ppmv})$. The analysis reveals that the diurnal variability in the lower SWV is controlled by the tropical tropopause temperature, whereas the middle and upper SWV is controlled by methane oxidation. The results are presented and discussed in the light of present understanding. 


\section{Introduction}

Water vapour $\left(\mathrm{H}_{2} \mathrm{O}\right)(\mathrm{WV})$ is one of the most important greenhouse gases which play a vital

26

27

28

29

role throughout the Earth's atmosphere in both chemistry and global radiative balance, especially in the upper troposphere and lower stratosphere (UTLS). Dessler et al. (2013) have estimated the climate feedback of about $+0.3 \mathrm{Wm}^{-2} \mathrm{~K}^{-1}$ due to an increase in the stratospheric water vapour (SWV), which is about 5-10\% responsible for the global warming from all the greenhouse gases. The primary source of hydroxyl ion $(\mathrm{OH})$ in the Earth's atmosphere is WV, and these $\mathrm{OH}-$ radicals control the lifetime of a shorter-lived greenhouse gas like ozone $\left(\mathrm{O}_{3}\right)$ and long-lived like methane $\left(\mathrm{CH}_{4}\right)$ (Seinfeld and Pandis, 2006 and references therein). Any variations from hourly to annual scale in the WV distribution have a significant impact on the global climate-weather system. For example, Forster and Shine (1999) observed that any increase in SWV acts to cool the stratosphere but warm the troposphere. Thus, the SWV plays an important role in stratospheric ozone chemistry and therefore, the global radiation budget.

In general, $\mathrm{SWV}$ increases with height due to the slow oxidation of $\mathrm{CH}_{4}$, at $25 \mathrm{~km}$ or higher, where stratospheric air is relatively aged (Waugh and Hall, 2002). Mote et al. (1996) established the fact that the large seasonal variation of SWV is associated with the tropical cold-point tropopause (CPT) temperature (CPT-T) which is named as "tape recorder effect". It is agreed that SWV is primarily controlled by the freeze-drying of air passing through the tropical CPT under the influence of the mean upward Brewer-Dobson circulation (BDC) (Dessler et al. 2013). In addition to the CPT temperature, other potential factors control the entry of WV to the lower stratosphere. Overshooting convection can significantly hydrate the lower stratosphere (Uma et al. 2014; Dessler et al. 2016) but overall it is less than $2 \%$ (Schoeberl et al. 2018). Besides, small-scale waves and the microphysical process can also hydrate UTLS (Fueglistaler et al. 
47 2013). It is observed that stronger convection leads to a relatively dry stratosphere, whereas

48 weaker convection leads to a wetter stratosphere (Randel et al. 2015). In addition to these

49 processes, Quasi-Biennial Oscillation (QBO) also controls the entry of WV to the lower 50 stratosphere (Dessler et al. 2014; Das and Suneeth, 2020). Once the WV enters the lower 51 stratosphere, it further propagates both vertically and quasi-horizontally (Rosenlof et al. 1997).

52 Many studies that deal with the seasonal, annual, and interannual variabilities of SWV, which are 53 further linked with the CPT temperature which is in principle controlled by convection, El Niño 54 Southern Oscillation (ENSO), and QBO (Dessler et al. 2014; Suneeth et al. 2017 and reference 55 therein). Solomon et al. (2010) discussed the contribution of SWV to the decadal changes in 56 global warming. Schwartz et al. (2008) characterized the role of Madden-Julian Oscillation in 57 hydrating the UTLS region. Suneeth and Das (2020) discussed the influence of Walker 58 circulation in the zonal asymmetry of WV. In addition to it, the entry of WV into the stratosphere 59 can be influenced by the overshooting convection, which can hydrate the lower stratosphere 60 (Dessler et al. 2016) and small-scale waves and microphysical process (Fueglistaler et al. 2013).

62 heating during the day and is accounted as the most fundamental component for the variability of 63 the climate-system (Gettelman and Rood, 2016). The strong coupling between WV and 64 temperature, even a diurnal scale can provide the basis for a strong positive WV feedback that amplifies the initial temperature changes induced by other greenhouse gases (e.g., $\mathrm{CO}_{2}$ ). The 66 periodic heating of the atmosphere by absorption of solar radiation (diurnal-annual) by WV, 67 which amplify both internal and external climate as well as by latent heat release excites 68 planetary-scale waves that propagate in the whole atmosphere, which can alter the circulation 69 and have a climate impact (Sherwood et al. 2010). Diurnal variation of tropospheric WV is also 
70 related to moist convection and precipitation, surface wind convergence, and surface evaporation

71 (Dai and Wang 2002). Tian et al. (2004) studied the diurnal variability of upper tropospheric WV

72 using Geostationary satellite and Chung et al. (2013) with reanalysis. Variability of relative

73 humidity in the diurnal scale is reported by Uma and Das (2016) using microwave sounder and

74 by radiosonde by Emmanuel et al. (2018). Earlier studies have found that the diurnal cycle of

75 tropical lower tropospheric WV lagged the variation in cloud cover by $2 \mathrm{hrs.} \mathrm{It} \mathrm{is} \mathrm{also} \mathrm{observed}$

76 that WV and upper tropospheric clouds are in-phase over land, whereas it is 12 hrs out-of-phase

77 over the Oceanic regions (Soden, 2000). This is attributed to the vertical structure of clouds over

78 the land and Ocean. Even though there are several studies on the diurnal variability of

79 tropospheric WV (Soden, 2000; Tian et al. 2004; Uma and Das, 2016), but, as far as the author's

80 knowledge there is no study reported so far in the diurnal variability of SWV, which is very

81 crucial for understanding climate change and forcing by absorbing solar short-wave infrared

82 radiation.

83 The maximum amount of WV and other pollutants are injected into the stratosphere over the

84 ASM region (Fu et al. 2006). Earlier studies have shown that the maximum amount of WV is

85 accumulated in the UTLS over the ASM anticyclone (Tibetan Plateau) during boreal summer

86 (Randel and Park, 2006; Das and Suneeth 2020). Nützel et al. (2019) found that ASM contributes

$8714 \%$ of SWV in tropics using a chemistry-transport model. It is also estimated that the ASM

88 can contribute $75 \%$ of the total net upward WV flux in the tropics from July-September

89 (Gettelman and Kinnison, 2004). The role of summertime convection over the ASM on SWV

90 was studied by Wright et al. (2011). Santee et al. (2017) quantified the impact of ASM

91 anticyclone in the climatological seasonal evolution in tracers of UTLS regions. Thus, the region

92 of interest for the present study is ASM (Equator to $40^{\circ} \mathrm{N}$ and $60-100^{\circ} \mathrm{E}$ ), which assumed to have 
93 the most distinct variation of the annual cycle and the alternation of dry and wet seasons, which

94 is in concert with the seasonal reversal of the monsoon circulation features (Webster et al. 1998).

95 The main intent of this paper is to present and discuss the diurnal variability of WV in the lower

96 and middle atmosphere (from the troposphere to stratosphere) in the ASM region, which is the

97 first of its kind and its linkage to the diurnal variability of CPT temperature and methane

98 oxidation using satellite measurements.

99

100

101

102

103

104

105

106

107

108

109

110

111

112

113

114

115

\section{Methodology and data analysis}

We used WV and temperature profiles measured by the Constellation Observing System for Meteorology, Ionosphere, and Climate (COSMIC) mission based on Global positioning SystemRadio Occultation measurement and Sounding of the Atmosphere using Broadband Emission Radiometry (SABER) onboard Thermosphere Ionosphere Mesosphere Energetics Dynamics (TIMED) satellite. Temperature and WV from COSMIC are obtained from moist air retrieval (wetPrf, level-2) (Kursinski et al. 1997) during 2006-2019. In SABER, temperature and WV are derived from 15 and $\sim 6.8 \mu \mathrm{m}$, respectively during 2001-2019 (Remsberg 2008; Rong et al. 2019). The vertical resolution of COSMIC is $100 \mathrm{~m}$ and SABER is $1 \mathrm{~km}$. A thorough quality check is done for both temperature and water vapour by removing the wild-points and outliers Since the temperature follows the normal distribution, thus we estimated monthly mean and $\pm 3 \sigma$ (where $\sigma$ is the standard deviation) and then remove the temperature data, which falls outside monthly mean $\pm 3 \sigma$ (outliers). A typical example for quality control of temperature for January 2007-2019 is shown in Figure S1. Water vapour distributions are skewed towards the higher values, thus we have estimated 0.25 and 99.75 percentiles and the data points which falls outside these percentile values are removed in the analysis. A typical example for quality control of water vapour is shown in Figure S2. In this process, we obtained $>90 \%$ of useful data. 
Diurnal composite profiles (every 3-hrs) for each month with a grid resolution of $5^{\circ}$ (latitude)

$117 \times 10^{\circ}$ (longitude) were generated and each grid has 30-40 and 60-75 profiles/month for COSMIC

118 and SABER, respectively. We have carried out the significant test (t-student test) and found that

119 the analysis of unevenly distributed data does not significantly affect our results due to the large 120 sample size.

121 The COSMIC derived temperature and WV are extensively validated with radiosonde, 122 Micro-limb sounder (MLS), Atmospheric Infrared Sounder (AIRS), and different reanalysis data 123 (Sun et al. 2010; Kishore et al. 2011; Rieckh et al. 2018). Individual WV profile from COSMIC 124 is accurate up to $8 \mathrm{~km}$ and mean up to $10 \mathrm{~km}$ with a fractional difference of $5-10 \%$. The 125 COSMIC temperature has an accuracy of $\sim 0.5$ and $0.1 \mathrm{~K}$ for individual and averaged profiles, 126 respectively (Kishore et al. 2009; Alexander et al. 2014). Rong et al. (2019) validated the WV 127 from SABER and Yue et al. (2019) utilized the data set for trend analysis. A total systematic 128 error, which is calculated as the root-sum-square of individual systematic sources is about 10$12920 \%$ and overall excellent agreement with a mean profile within $\pm 10 \%$. SABER temperature is 130 well compared with other measurements and found a precision of $\sim 1 \mathrm{~K}$ (Remsberg et al. 2003).

\section{3. Results and discussions}

\section{3.1. Climatology of WV}

Figure 1 shows the seasonal mean distribution of WV mixing ratio (WMR) at 6, 8, 16, 134 25, 40, and $50 \mathrm{~km}$ for four seasons, i.e. December-January-February (DJF), March-April-May 135 (MAM), June-July-August (JJA), and September-October-November (SON). The close contour 136 during JJA at $16 \mathrm{~km}$ indicates the climatological locations of ASM-anticyclone following Park et 137 al. (2007). Tropospheric WV is high and maximum is found over the south-east of ASM138 anticyclone during JJA. WV at 6 and $8 \mathrm{~km}$ are high over the Tibetan plateau during JJA. At 16 
$139 \mathrm{~km}$, the WV is high (6-8 ppmv) between the equator and $15^{\circ} \mathrm{N}$; however, during JJA and SON

140 the increase extended up to $40^{\circ} \mathrm{N}$. Monsoon season acts as one of the significant sources of WV,

141 and several studies discussed the transport of WV into the UTLS region (Randel et al. 2015).

142 Above $16 \mathrm{~km}, \mathrm{WV}$ is found to be very less, and between $25-40 \mathrm{~km}$, it is about 4-5 ppmv and

143 does not have drastic seasonal characteristics as we observed in the troposphere. At $40 \mathrm{~km}, \mathrm{WV}$

144 is high ( 7 ppmv) in mid-latitude regions compared to the tropics, especially during DJF. At 50

$145 \mathrm{~km}$ over the entire ASM region, the WV is about 7 ppmv during all the seasons. The seasonal

146 characteristics of WV measured by the COSMIC-1 and SABER are similar to the other satellite

147 measurements as reported earlier. For example, near the tropopause $(\sim 16 \mathrm{~km}$ or $100 \mathrm{hPa})$ both

148 SABER and MLS show WV of 6-8 ppmv with similar distributions (Randel and Park 2006).

149 3.2. Diurnal variability of WV and temperature

150 We divide the ASM into three regions: R1, R2, and R3 based on the intensity of convection.

$151 \mathrm{R} 1$ covers the deep-equator from Equator $-10^{\circ} \mathrm{N}, \mathrm{R} 2$ is the central part of ASM, which is the 152 monsoon active region from $15-25^{\circ} \mathrm{N}$ and R3 covers ASM-anticyclone from $30-40^{\circ} \mathrm{N}$. Figure 2

153 shows the diurnal variability of WV for different seasons/regions from 2-65 km. The mean 154 removed diurnal variability shown in Figure 3 and its standard errors in Figure S3 155 (supplementary figure). We also plotted seasonal time-series of diurnal variability of WV at 6, 8, $15616,25,40$, and $50 \mathrm{~km}$ as shown in Figure $\mathrm{S} 4$ to see the inter-annual consistency. The maximum 157 extent of WV is observed during JJA for all regions. Strong diurnal variability is observed 158 (Figure 3) in all the regions/seasons and has inter-annual consistency (Figure S4). All the 159 regions/seasons show the variability of WV within $\pm 400 \mathrm{ppmv}( \pm 1 \mathrm{ppmv})$ at $2-10 \mathrm{~km}(15-65 \mathrm{~km})$ 160 and have phase propagation similar to tidal waves. In the troposphere $(<16 \mathrm{~km})$, maximum WV 161 is observed during 9-18 LT. WV in the UTLS region is also found to be high ( 0.8 ppmv) during 
9-18 LT. Similarly, enhanced WV is observed during 9-18 LT between 25-35 km. Between 25$35 \mathrm{~km}$, the air is relatively aged (Waugh and Hall, 2002), which is attributed to slow $\mathrm{CH}_{4}$ oxidation by the following reactions (Seinfeld and Pandis 2006):

$$
\begin{aligned}
& \mathrm{CH} 4+\mathrm{OH} \rightarrow \mathrm{CH}_{3}+\mathrm{H}_{2} \mathrm{O} \\
& \mathrm{CH} 4+\mathrm{O}\left({ }^{1} \mathrm{D}\right) \rightarrow \mathrm{CH}_{3}+\mathrm{OH}
\end{aligned}
$$

$\mathrm{CH}_{4}$ is also long-lived species in the stratosphere, which is transported from the surface and found to be $\sim 1.2 \mathrm{ppmv}$ in the stratosphere. When the intensity of ultraviolet (UV) radiation increases from forenoon to afternoon, the WV in the stratosphere reacts with ozone between 25$35 \mathrm{~km}$ (maximum ozone) to form $\mathrm{OH}$-radicals by the following reactions:

The key production of $\mathrm{OH}$ in the stratosphere is initiated by photolysis of $\mathrm{O}_{3}$ to produce $\mathrm{O}\left({ }^{1} \mathrm{D}\right)$ by the following reaction (Seinfeld and Pandis 2006) :

$$
\begin{aligned}
& \mathrm{O} 3+h v \rightarrow \mathrm{O}_{2}+\mathrm{O}\left({ }^{1} \mathrm{D}\right) \\
& \mathrm{O}\left({ }^{1} \mathrm{D}\right)+\mathrm{H}_{2} \mathrm{O} \rightarrow 2 \mathrm{OH} \\
& \mathrm{O}\left({ }^{1} \mathrm{D}\right)+\mathrm{CH}_{4} \rightarrow \mathrm{OH}+\mathrm{CH}_{3} \\
& \mathrm{H}_{2} \mathrm{O}+h v \rightarrow \mathrm{OH}+\mathrm{H}
\end{aligned}
$$

The total rate of $\mathrm{OH}$ production between $20-50 \mathrm{~km}$ from equation-4 and equation-5 is $1.8 \times 10^{4}$ molecules $\mathrm{cm}^{-3} \mathrm{~s}^{-1}$ and $0.2 \times 10^{4}$ molecules $\mathrm{cm}^{-3} \mathrm{~s}^{-1}$ (Seinfeld and Pandis 2006). These OHradicals form during the daytime and maximize $\left(2 \times 10^{4}\right.$ molecules $\left.\mathrm{cm}^{-3}\right)$ during $10-14 \mathrm{LT}$ and reacts with methane (equation-1) to form WV (Seinfeld and Pandis 2006). The associated rate coefficient for equation- 6 is estimated as $k_{1}=1.09 \times 10^{-15} \mathrm{~cm}^{3}$ molecule s $\mathrm{s}^{-1}$ at $230 \mathrm{~K}(\sim 30 \mathrm{~km})$ and thus the production rate of $\mathrm{H}_{2} \mathrm{O}$ from methane oxidation (equation-6) is $\sim 1.2 \times 10^{3}$ molecules $\mathrm{cm}^{-3} \mathrm{~s}^{-1}$. A modelling study by Zahn et al. (2006) also shows net $\mathrm{H}_{2} \mathrm{O}$ production due to methane oxidation is $\sim 2500$ molecules $\mathrm{cm}^{-3} \mathrm{~s}^{-1}$. The estimated water vapour from methane oxidation is 
0.4 ppmv per $24 \mathrm{hrs}$ between $25-35 \mathrm{~km}$, which consistent with the observations. Thus the observed enhancement of WV between $25-35 \mathrm{~km}$ during 9-18 LT is due to the availability of OH-radicals. At higher altitudes $(>35 \mathrm{~km})$, the time of enhancement in the WV decreases with altitude from 3-6 LT, which is attributed to the availability of UV radiation. At $45 \mathrm{~km}$, it is maximizing ( 0.8 ppmv) at 0-6 LT, and at $60 \mathrm{~km}$ it is during 6-9 LT.

Diurnal mean removed temperature for different regions/seasons is shown in Figures 4 and its standard error in Figure S5 (supplementary figure). Diurnal variability is $< \pm 0.5 \mathrm{~K}$ in the troposphere, whereas in the stratosphere it is about $\pm 2 \mathrm{~K}$ for all the regions. Lower troposphere and between 35-60 km are warmer for all regions during 12-18 LT and more during JJA. The UTLS region is warmer during 6-12 LT for all regions/seasons. This pattern weakens during SON. Distinct semi-diurnal variation is observed above $35 \mathrm{~km}$ and up to $65 \mathrm{~km}$, showing the presence of semi-diurnal tides for all the regions/seasons. There are many studies on diurnal tides using temperature profiles measured from COSMIC-1 (e.g., Xie et al. 2010 ) and SABER (e.g., Sakazaki et al. 2018), thus we are not discussing further.

\subsection{Correlation between water vapour and temperature}

To get further insight into the variability and the relationship between WV and temperature, we have shown the time-series (absolute) plots at 6, 8, 16, 25, 40, and $50 \mathrm{~km}$ for different regions (R1, R2, and R3) and seasons as shown in Figures 5 a-f. WV variability is in phase with temperature between 6-16 km for all regions/seasons. The holding capacity of WV in dry air depends on the saturation missing ratio (SMR) and thus WV and temperature are in phase. However, we observed a phase lag of 3-hrs between temperature and WV for R3, which could be due to deep-convection over this region. Deep-convection has warm anomalies between 10-14 $\mathrm{km}$ as well above CPT (<1 K) (Johnston et al. 2018). Since WV lag deep-convection by $2 \mathrm{hr}$ 
overland (Soden 2000), thus there is a phase lag between temperature and WV over R3. The deep-convection generates cirrus anvil clouds that can further moisten the upper troposphere by the evaporation of the cirrus anvil. Thus, the temperature near the tropopause, overshooting convection, and cirrus anvil are the few factors that control the diurnal variation of $\mathrm{WV}$ in the UTLS region.

WV and temperature are always out-of-phase above $25 \mathrm{~km}$ in all the regions/seasons (Figure S8 d). As discussed earlier, methane oxidation occurs between 25-35 km. The maximum WV occurs during 9-18 LT in all regions/seasons, which is attributed to the availability of $\mathrm{OH}$-radials during day-time as discussed above. The phase delay of $\sim 12$ is observed between WV and temperature for R1 and R2, whereas for R3 it is $\sim 6 \mathrm{hr}$. Above $30 \mathrm{~km}$ (Figures $5 \mathrm{e}-\mathrm{f}$ ) WV and temperature show opposite phases for all seasons/regions and the maximum WV is observed during 0-9 LT, maximizing at $6 \mathrm{LT}$. This may be due to the availability of $\mathrm{OH}$ radical in the presence of UV radiation, which is available much earlier in the early morning. The maximum temperature is observed during 12-18 LT. Both WV and temperature show distinct diurnal variation indicating the influence of diurnal tides with a phase difference of $12 \mathrm{hrs}$.

Figure 6 shows the CPT-T and altitude (CPT-A) for different seasons for R1 and R2 along with the diurnal mean removed WV and saturation missing ratio (SMR). We used lapse rate tropopause temperature (LRT-T) and altitude (LRT-A) for R3, as we cannot detect CPT except for JJA. The tropopause is warmer by $0.6-1 \mathrm{~K}$ during $6-15 \mathrm{LT}$ for all seasons for R1 and R2 and we also observed maximum WV during 9-18 LT. The tropopause altitude varies between 16.8 to $17.5 \mathrm{~km}$ for R1 and R2. Similar warmer tropopause and high WV are found for R3, but DJF and MAM. During JJA and SON in R3, the tropopause is warmer during 0-9 and high WV is observed during 9-15 LT. LRT-A varies between 11-15 km for R3, maximizing during JJA, 
231 which is in contrast to R1 and R2 (Das and Suneeth 2020). SWV is strongly coupled to the 232 tropopause temperature (e.g., Randel et al. 2013), which is not only restricted to the annual cycle

233 (like tape-recorder effect, Mote et al. 1996) but also to the diurnal scale as observed in the 234 present analysis. Thus more amount of WV in the lower stratosphere is due to the tropopause 235 temperature.

236 Further, we correlate the temperature and WV for all regions/seasons as shown in Figure 7. A 237 high correlation is observed between temperature and WV near the tropopause, indicating that 238 tropopause temperature controls the SWV, which is more or less consistent for all regions and 239 seasons. We also observed a high correlation between $30-35 \mathrm{~km}$, where methane oxidation takes 240 place as discussed above. Thus, the temperature in UTLS region and between $25-35 \mathrm{~km}$ is the 241 controlling factor for SWV.

\section{$242 \quad 3.4$ Diurnal amplitude and phase}

243 Further, the diurnal amplitude and phases are extracted for both WV and temperature for 244 all regions/seasons as shown in Figure 8. For WV (temperature), diurnal amplitude and phase are 245 extracted between 5-10 km (5-35 km) from COSMIC and 15-60 km (15-60 km) from SABER. 246 The amplitude of WV is high in the lower troposphere which is well documented in the literature 247 (e.g., Soden 2000; Tian et al. 2004; Uma and Das 2016), thus we will emphasize more discussion 248 on diurnal variability WV near the tropopause and the entire stratosphere. WV amplitude of 249 about 0.3-0.4 ppmv is found near the tropopause. Over R1, we observed bimodal peaks, one at $250 \quad 25-30 \mathrm{~km}(0.4 \mathrm{ppmv})$ and the other at $45-55 \mathrm{~km}(0.6 \mathrm{ppmv})$. The bimodal peak is also observed 251 in R2 and R3 in line with R1, but the second peak occurs between 40 and $45 \mathrm{~km}$. It is interesting 252 to note that the amplitude of both the peaks in R2 is the same and found to be 0.4 ppmv. Over $253 \mathrm{R} 3$, the amplitude of the primary peak $(25-30 \mathrm{~km})$ is more than the secondary peak. The 
254 characteristic of amplitude in $\mathrm{WV}$ is almost similar in all the seasons except the occurrence

255 height of the secondary peak, which varies within $5 \mathrm{~km}$. Forster and Shine (1999) have shown a

256 strong radiative forcing due to the increase of SWV. They estimate that $0.7 \mathrm{ppmv}$ increase in

257 SWV would result in a radiation forcing of $0.19-0.29 \mathrm{Wm}^{-2}$. We estimate the net radiative

258 forcing of $\sim 0.4 \mathrm{Wm}^{-2}$ for the diurnal variability SWV of 0.4-0.6 ppmv using SBDART

259 (Ricchiazzi et al. 1998). Thus the diurnal component of SWV has a good impact on the Earth's 260 radiation budget.

261 The phase is random in the troposphere, whereas from the tropopause to $35 \mathrm{~km}$, the phase

262 is during 12-16 hrs in all three regions. Downward phase propagation is observed from 4 to 8 hrs

263 between $35-45 \mathrm{~km}$. Like amplitude, all seasons show similar phase profiles. Diurnal amplitude in

264 temperature shows four peaks, viz. 16-18 km (near tropopause), 30-35 km, 45-50 km and 60

$265 \mathrm{~km}$. Both the peaks in $\mathrm{WV}$ and temperature in $\mathrm{R} 1$ coincide, however, the secondary peak

266 slightly varies within $5 \mathrm{~km}$. Over R2 and R3, there is no significant amplitude peak in

267 temperature below $35 \mathrm{~km}$. However, the enhanced amplitude is observed between $45-55 \mathrm{~km}$ over

268 R2 and R3 for all the seasons. Clear downward phase propagation is observed between 10 and 40

$269 \mathrm{~km}$ in all regions/seasons. There is no phase propagation above $40 \mathrm{~km}$. Diurnal amplitude and

270 phase profiles in temperature are well established (Xie et al. 2010; Sakazaki et al. 2018). The

271 common amplitude and phase profiles of temperature (15-35 km) derived from COSMIC and

272 SABER shows the same characteristics. Even though the amplitude of diurnal amplitude of

273 temperature is very less near the tropopause, but we observe enhanced diurnal amplitude in WV.

274 Between 25 and $35 \mathrm{~km}$ and between 45 and $55 \mathrm{~km}$, both temperature and WV show enhanced

275 diurnal amplitude with $\pm 5 \mathrm{~km}$ variability in the peak altitude. Both temperature and WV show

276 similar downward phase propagation. 


\section{Concluding remarks}

278 In this study, the vertical structure of the diurnal variability of SWV and its controlling

279 factor is presented. We find the diurnal variability of lower SWV is mainly controlled by the 280 tropopause temperature, whereas in the middle and upper stratosphere it is mainly controlled by

281 methane oxidation in addition to temperature. We also show the amplitude and phase profiles of 282 diurnal variation of water vapour and temperature for different seasons. Bimodal and a trimodal 283 distribution of diurnal amplitude in water vapour are observed. A systematic phase difference is 284 noted between the water vapour and temperature, which is very consistent in the stratosphere. 285 The present study has shown the diurnal variability of SWV over the ASM region, which is the 286 first of its kind. Further investigations are essential to evaluate the role of small-scale waves and 287 turbulence occurring in the upper troposphere and lower stratosphere region to an understanding 288 of the observations presented here.

289 Data availability

290 The data used in the present study are downloaded from the following websites:

291 SABER: http://saber.gats-inc.com/data.php

292 COSMIC: http://cdaac-www.cosmic.ucar.edu/cdaac/index.html.

293 Declaration of competing for interest

294 The authors declare that there is no conflict of interest.

295 Acknowledgments 
296 The authors are greatly appreciative to the teams of SABER-TIMED and the COSMIC Data 297 Analysis and Archive Centre, and sincerely acknowledged them for providing the data used in 298 this study.

\section{References}

302

303

304

305

306

307

308

309

310

Alexander P, de la Torre A, Llamedo P, Hierro R (2014) Precision estimation in temperature and refractivity profiles retrieved by GPS radio occultations. J Geophys Res : Atmos, 119(14), 8624-8638. doi : 10.1002/2013JD021016

Chung ES, Soden BJ, Sohn BJ, Schmetz J (2013) An assessment of the diurnal variation of upper tropospheric humidity in reanalysis data sets. J Geophys Res : Atmos, 118(9), 34253430. https://doi.org/10.1002/jgrd.50345

Dai A, Wang J, Ware RH, Van Hove T (2002) Diurnal variation in water vapor over North America and its implications for sampling errors in radiosonde humidity. J Geophys Res : Atmos, 107(D10), ACL-11. https://doi.org/10.1029/2001JD000642

Das SS, Suneeth KV (2020) Seasonal and interannual variations of water vapor in the upper troposphere and lower stratosphere over the Asian Summer Monsoon region-in perspective of the tropopause and ocean-atmosphere interactions. J Atmos Sol-Terr Phys, 105244, https://doi.org/10.1016/j.jastp.2020.105244

Dessler AE, Schoeberl MR, Wang T, Davis SM, Rosenlof KH (2013) Stratospheric water vapor feedback. Proc Natl Acad Sci USA, 110(45), 18087-18091. https://doi.org/10.1073/pnas.1310344110 
Dessler AE, Schoeberl MR, Wang T, Davis SM, Rosenlof KH, Vernier JP (2014) Variations of stratospheric water vapor over the past three decades. J Geophys Res : Atmos, 119(22), 12588, https://doi.org/10.1002/2014JD021712

Dessler AE, Ye H, Wang T, Schoeberl MR, Oman LD, Douglass AR, et al. (2016) Transport of ice into the stratosphere and the humidification of the stratosphere over the 21st century. Geophys Res Lett, 43(5), 2323-2329. https://doi.org/10.1002/2016GL067991

Emmanuel M, Sunilkumar SV, Ratnam MV, Muhsin M, Parameswaran K, Murthy BK (2018) Diurnal variation of the tropospheric water vapour over a coastal and an inland station in Southern Indian Peninsula. J Atmos Sol-Terr Phys, 179, 11-21. https://doi.org/10.1016/j.jastp.2018.06.007

Forster PMDF, Shine KP (1999) Stratospheric water vapour changes as a possible contributor to observed stratospheric cooling. Geophys Res Lett, 26(21), 3309-3312, https://doi.org/10.1029/1999GL010487

Fueglistaler S, Liu YS, Flannaghan TJ, Haynes PH, Dee DP, Read WJ, ... Bernath PF (2013) The relation between atmospheric humidity and temperature trends for stratospheric water. J Geophys Res : Atmos, 118(2), 1052-1074. https://doi.org/10.1002/jgrd.50157

Fu R, Hu Y, Wright JS, Jiang JH, Dickinson RE, Chen M, Filipiak M, Read WG, Waters JW, Wu DL (2006) Short circuit of water vapor and polluted air to the global stratosphere by convective transport over the Tibetan Plateau. Proc Natl Acad Sci USA. 103 (15), 56645669. https://doi.org/10.1073/pnas.0601584103.

Gettelman A, Kinnison DE, Dunkerton TJ, Brasseur GP (2004). Impact of monsoon circulations on the upper troposphere and lower stratosphere. J Geophys Res : Atmos, 109(D22).https://doi.org/10.1029/2004JD004878 
341 Gettelman A, Rood RB (2016) Components of the Climate System. In: Demystifying Climate

342

343

344

345

346

347

348

349

350

351

352

353

354

355

356

357

358

359

360

361

362

Models. Earth Systems Data and Models, vol 2. Springer, Berlin, Heidelberg. https://doi.org/10.1007/978-3-662-48959-8_2

Johnston BR, Xie F, Liu C (2018) The effects of deep convection on regional temperature structure in the tropical upper troposphere and lower stratosphere. J Geophys Res : Atmos, 123(3), 1585-1603. https://doi.org/10.1002/2017JD027120

Kursinski ER, Hajj GA, Schofield JT, Linfield RP, Hardy KR (1997) Observing Earth's atmosphere with radio occultation measurements using the Global Positioning System. J Geophys Res : Atmos, 102(D19), 23429-23465. https://doi.org/10.1029/97JD01569

Kishore P, Namboothiri SP, Jiang JH, Sivakumar V, Igarashi K (2009) Global temperature estimates in the troposphere and stratosphere: a validation study of COSMIC/FORMOSAT-3 measurements. Atmos Chem Phys, 9, 897-908, https://doi.org/10.5194/acp-9-897-2009

Kishore P, Ratnam MV., Namboothiri SP, Velicogna I, Basha G, Jiang JH, Igarashi K, Rao SVB, Sivakumar V (2011) Global (50 degrees S-50 degrees N) distribution of water vapor observed by COSMIC GPS RO: Comparison with GPS radiosonde, NCEP, ERA-Interim, and JRA-25 reanalysis data sets. J Atmos Sol-Terr Phys, 73. https://doi.org/10.1016/j.jastp.2011.04.017

Mote PW, Rosenlof KH, McIntyre ME, Carr ES, Gille JC, Holton JR, ... Waters JW (1996). An atmospheric tape recorder: The imprint of tropical tropopause temperatures on stratospheric water vapor. J Geophys Res : Atmos, 101(D2), 3989-4006.

https://doi.org/10.1029/95JD03422 
Nützel M, Podglajen A, Garny H, Ploeger F (2019) Quantification of water vapour transport from the Asian monsoon to the stratosphere. Atmos Chem Phys, 19(13). https://doi.org/10.5194/acp-19-8947-2019

Park, M, Randel WJ, Gettelman A, Massie ST, Jiang JH (2007) Transport above the Asian summer monsoon anticyclone inferred from Aura Microwave Limb Sounder tracers. J Geophys Res : Atmos, 112(D16).https://doi.org/10.1029/2006JD008294

Randel WJ, Park M (2006) Deep convective influence on the Asian summer monsoon anticyclone and associated tracer variability observed with Atmospheric Infrared Sounder (AIRS). J Geophys Res : Atmos, 111(D12). https://doi.org/10.1029/ 2005JD006490

Randel WJ, Jensen EJ (2013) Physical processes in the tropical tropopause layer and their roles in a changing climate. Nat Geosci, 6(3), 169-176.https://doi.org/10.1038/ngeo1733

Randel WJ, Zhang K, Fu R (2015) What controls stratospheric water vapor in the NH summer monsoon regions?. J Geophys Res : Atmos, 120(15), 7988-8001. https://doi.org/10.1002/2015JD023622

Remsberg E, Lingenfelser G, Harvey VL, Grose W, Russell III J, Mlynczak M, ... Marshall, BT (2003) On the verification of the quality of SABER temperature, geopotential height, and wind fields by comparison with Met Office assimilated analyses. J Geophys Res : Atmos, 108(D20). https://doi.org/10.1029/2003JD003720

Ricchiazzi P, Yang S, Gautier C, Sowle D (1998) SBDART: A research and teaching software tool for plane-parallel radiative transfer in the Earth's atmosphere. Bull Amer Meteo Soc, 79(10), 2101-2114.https://doi.org/10.1175/1520-0477(1998)079<2101:SARATS>2.0.CO;2 
Rieckh T, Anthes R, Randel W, Ho SP, Foelsche U (2018) Evaluating tropospheric humidity from GPS radio occultation, radiosonde, and AIRS from high-resolution time series. Atmos Meas Tech, 11(5), 3091-3109.https://doi.org/10.5194/amt-11-3091-2018

Rong P, Russell III JM, Marshall BT, Gordley LL, Mlynczak MG, Walker KA (2019) Validation of water vapor measured by SABER on the TIMED satellite. J Atmos Sol-Terr Phys, 194, 105099. doi :10.1016/j.jastp.2019.105099

Rosenlof KH, Tuck AF, Kelly KK, Russell III JM, McCormick MP (1997) Hemispheric asymmetries in water vapor and inferences about transport in the lower stratosphere. J Geophys Res : Atmos, 102(D11), 13213-13234. https://doi.org/10.1029/97JD00873

Sakazaki T, Fujiwara M, Shiotani M (2018) Representation of solar tides in the stratosphere and lower mesosphere in state-of-the-art reanalyses and in satellite observations. Atmos Chem Phys, 18(2), 1437-1456. https://doi.org/10.5194/acp-18-1437-2018

Santee ML, Manney GL, Livesey NJ, Schwartz MJ, Neu JL, Read WG (2017) A comprehensive overview of the climatological composition of the Asian summer monsoon anticyclone based on 10 years of Aura Microwave Limb Sounder measurements. J Geophys Res : Atmos, 122(10), 5491-5514. https://doi.org/10.1002/2016JD026408.

Schwartz MJ, Lambert A, Manney GL, Read WG, Livesey et. al., (2008) Validation of the Aura Microwave Limb Sounder temperature and geopotential height measurements. J Geophys Res : Atmos, 113(D15). https://doi.org/10.1029/2007JD008783

Schoeberl MR, Jensen EJ, Pfister L, Ueyama R, Avery M, Dessler AE (2018) Convective hydration of the upper troposphere and lower stratosphere. J Geophys Res : Atmos, 123, 4583-4593. https://doi.org/10.1029/2018JD028286 
Sherwood SC, Roca R, Weckwerth TM, Andronova NG (2010) Tropospheric water vapor, convection, and climate. Rev Geophys, 48(2). https://doi.org/10.1029/2009RG000301

Seinfeld JH and Pandis SN (2006) Atmos Chem Phys: From Air Pollution to Climate Change. 2nd Edition, John Wiley Sons, New York. ISBN: 978-1-118-94740-1

Soden BJ (2000) The diurnal cycle of convection, clouds, and water vapor in the tropical upper troposphere. Geophys Res Lett, 27(15), 2173-2176. https://doi.org/10.1029/2000GL011436

Solomon S, Rosenlof KH, Portmann RW, Daniel, JS, Davis, SM, Sanford TJ, Plattner GK (2010) Contributions of stratospheric water vapor to decadal changes in the rate of global warming. Sci, 327(5970), 1219-1223. https://doi.org/10.1126/science.1182488

Sun B, Reale A, Seidel DJ, Hunt DC (2010) Comparing radiosonde and COSMIC atmospheric profile data to quantify differences among radiosonde types and the effects of imperfect collocation on comparison statistics. J Geophys Res : Atmos, 115(D23). https://doi.org/10.1029/2010JD014457

Suneeth KV, Das SS, Das SK (2017) Diurnal variability of the global tropical tropopause: results inferred from COSMIC observations. Clim Dyn, 49(9-10), 32773292.https://doi.org/10.1007/s00382-016-3512-x

Suneeth KV, Das SS (2020) Zonally resolved water vapour coupling with tropical tropopause temperature: Seasonal and interannual variability, and influence of the Walker circulation. Clim Dyn. https://doi.org/10.1007/s00382-020-05255-w

Tian B, Soden BJ, Wu X (2004) Diurnal cycle of convection, clouds, and water vapor in the tropical upper troposphere: Satellites versus a general circulation model. J Geophys Res : Atmos, 109(D10). https://doi.org/10.1029/2003JD004117 
Uma KN, Das SK, Das SS (2014) A climatological perspective of water vapor at the UTLS region over different global monsoon regions: observations inferred from the Aura MLS and reanalysis data. Clim Dyn, 43(1-2), 407-420. https://doi.org/ 10.1007/s0038-014-20859

Uma KN, Das SS (2016) Quantitative and qualitative assessment of diurnal variability in tropospheric humidity using SAPHIR onboard Megha-Tropiques. J Atmos Sol-Terr Phys, 146, 89-100. https://doi.org/10.1016/j.jastp.2016.05.009

Waugh D, Hall T (2002) Age of stratospheric air: Theory, observations, and models. Rev Geophys, 40(4), 1-1. https://doi.org/10.1029/2000RG000101

Webster PJ, Magana VO, Palmer TN, Shukla J, Tomas RA, Yanai MU, Yasunari T (1998) Monsoons: Processes, predictability, and the prospects for prediction. J Geophy Res: Oce, 103(C7), 14451-14510.https://doi.org/10.1029/97JC02719

Wright JS, Fu R, Fueglistaler S, Liu YS, Zhang Y (2011) The influence of summertime convection over Southeast Asia on water vapor in the tropical stratosphere. J Geophys Res : Atmos, 116(D12). https://doi.org/10.1029/2010JD015416

Xie F, Wu DL, Ao CO, Mannucci AJ (2010) Atmospheric diurnal variations observed with GPS radio occultation soundings. Atmos Chem Phys, 10(14), 68896899.https://doi.org/10.5194/acp-10-6889-2010

Yue J, Russell III J, Gan Q, Wang T, Rong P, Garcia R, Mlynczak M (2019) Increasing water vapor in the stratosphere and mesosphere after 2002. Geophys Res Lett, 46 (22), 1345213460. doi :10.1029/2019GL084973 
449 Zahn A, Franz P, Bechtel C, Grooß JU, Röckmann T (2006) Modelling the budget of middle

450 atmospheric water vapour isotopes. Atmos Chem Phys, 6, 2073-2090,

451 https://doi.org/10.5194/acp-6-2073-2006

452

453

454

455

456

457

458

459

460

461

462

463

464

465

466

467

468

469

470

471 


\section{$472 \quad$ Figure Captions}

473 Figure 1. Seasonal mean latitude-longitude distribution of water vapour at 6, 8, 16, 25, 40, and 47450 km for December-January-February (DJF), March-April-May (MAM), June-July-August 475 (JJA), and September-October-November (SON). Water vapour mixing ratio up to $8 \mathrm{~km}$ is 476 measured using COSMIC-1 from December 2006 to November 2019, and from 16 km onwards 477 to higher levels are derived from TIMED-SABER from January 2002 to December 2019. Black 478 closed contour (at 6,8 and $16.5 \mathrm{~km}$ ) indicates the climatological location of the Asian summer 479 monsoon (ASM) anticyclone during JJA as defined by Park et al., (2007) by defining a stream 480 function contour.(400 $\mathrm{m}^{2} \mathrm{~s}^{-1}$ ) (for more detail please refer Park et al. 2007 and Santee et al. 481 2017).

482 Figure 2. Diurnal variability of water vapour mixing ratio (WMR) for different seasons of 483 Region-1 (R1), Region-2 (R2), and Region-3 (R3) (see text for region averaging). COSMIC 484 derived water vapour is from 2-10 km, whereas SABER derived is from 15-65 km.

485 Figure 3. Same as Fig.2, but for diurnal mean removed.

486 Figure 4. Diurnal variability of temperature (diurnal mean removed) for different seasons of 487 Region-1 (R1), Region-2 (R2), and Region-3 (R3). COSMIC derived temperature is from 0-35 $488 \mathrm{~km}$, whereas SABER derived is from $15-65 \mathrm{~km}$.

489 Figure 5. Diurnal variability of water vapour mixing ratio (WMR) (blue) and temperature (T) 490 (red) at (a) 6 and (b) $8 \mathrm{~km}$ from COSMIC, and (c) 16, (d) 25, (e) 40 and (f) $50 \mathrm{~km}$ from SABER 491 measurements for different seasons for Region-1 (R1), Region-2 (R2), and Region-3 (R3).

492 Figure 6. Diurnal variability of mean removed water vapour mixing ratio (WMR) (black) and 493 saturation mixing ratio (SMR) (red) at 17-18 $\mathrm{km}$ derived from SABER, tropopause altitude 494 (blue), tropopause temperature (magenta) derived from COSMIC temperature profiles for 
495 different seasons of Region-1 (R1), Region-2 (R2), and Region-3 (R3). Cold-point tropopause 496 altitude (CPT-A) and temperature (CPT-T) are estimated for Region-1 and -2, whereas lapse rate 497 tropopause (LRT) is estimated for Region-3, as well-defined CPT cannot be obtained for Region4983 , except for JJA. Vertical lines indicate the respective standard errors.

499 Figure 7. Height profiles of correlation coefficient (r) between WMR and temperature (T) for 500 different seasons of Region-1, Region-2, and Region-3. The profiles from 5-10 km (5-25 km) are 501 from COSMIC derived WMR (T), whereas the profile from 15-60 km is from SABER derived 502 WMR and T.

503 Figure 8. Height profiles of diurnal amplitude and phase of (a) WMR, and (b) temperature for 504 different seasons at Region $-1,-2,-3$. The profiles from 5-10 km (5-25 km) are from COSMIC 505 derived WMR (T), whereas the profile from 15-60 km is from SABER derived WMR and T. 506

\section{Supplementary Figures}

508 Figure S1. Temperature profiles (black) before (left) and after (right) quality control for January $509(2007-2019)$ between $0-10^{\circ} \mathrm{N}$ and $60-100^{\circ} \mathrm{E}$. Red and green lines in left panel indicate the $-3 \sigma$ 510 and $+3 \sigma$, respectively for the month of January of same grid.

511 Figure S2. Water vapour mixing ratio (WMR) profiles (black) before (left) and after (right) 512 quality control for January (2007-2019) between $0-10^{\circ} \mathrm{N}$ and $60-100^{\circ} \mathrm{E}$. Red and green lines in 513 left panel indicate the 0.25 percentile and 99.75 percentile, respectively for the month of January 514 of same grid.

515 Figure S3. Same as Fig.2, but for standard errors (water vapour). 
516 Figure S4. (left panels) Time-series of water vapour mixing ratio for different seasons at (a) 6

$517 \mathrm{~km}$, (b) $8 \mathrm{~km}$, (c) $16 \mathrm{~km}$, (d) $25 \mathrm{~km}$, (d) $40 \mathrm{~km}$, and (e) $50 \mathrm{~km}$ along with its (right panels)

518 standard error for Region-1 (R1), Region-2 (R2), and Region-3 (R3).

519 Figure S5. Same as Fig.4, but for standard error (temperature).

520

521 
Figure 1. Seasonal mean latitude-longitude distribution of water vapour at $6,8,16,25,40$, and $50 \mathrm{~km}$ for December-January-February (DJF), March-April-May (MAM), June-JulyAugust (JJA), and September-October-November (SON). Water vapour mixing ratio up to 8 $\mathrm{km}$ is measured using COSMIC-1 from December 2006 to November 2019, and from $16 \mathrm{~km}$ onwards to higher levels are derived from TIMED-SABER from January 2002 to December 2019. Black closed contour (at 6, 8 and $16.5 \mathrm{~km}$ ) indicates the climatological location of the Asian summer monsoon (ASM) anticyclone during JJA as defined by Park et al., (2007) by defining a stream function contour.(400 $\left.\mathrm{m}^{2} \mathrm{~s}^{-1}\right)$ (for more detail please refer Park et al. 2007 and Santee et al. 2017).
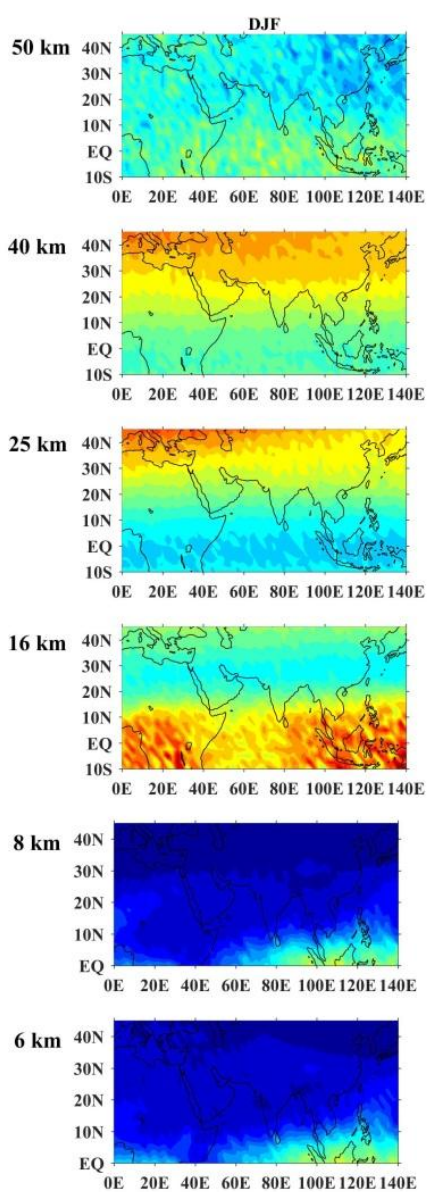
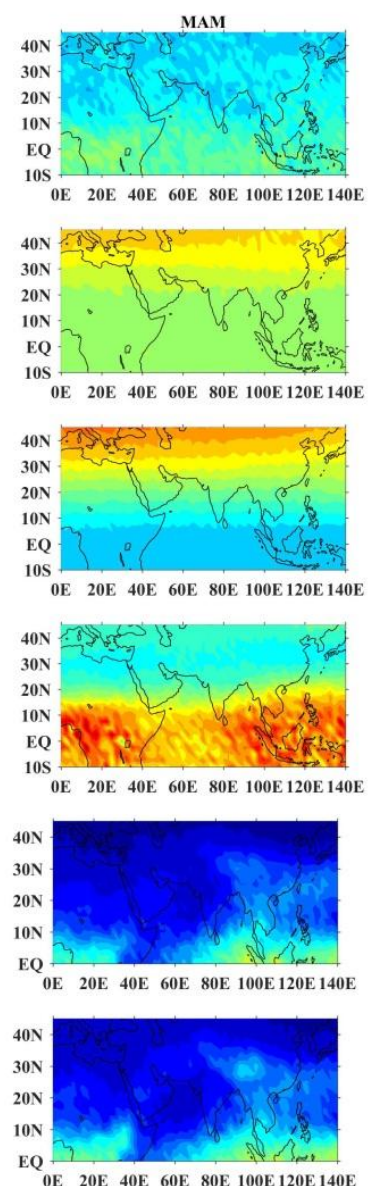
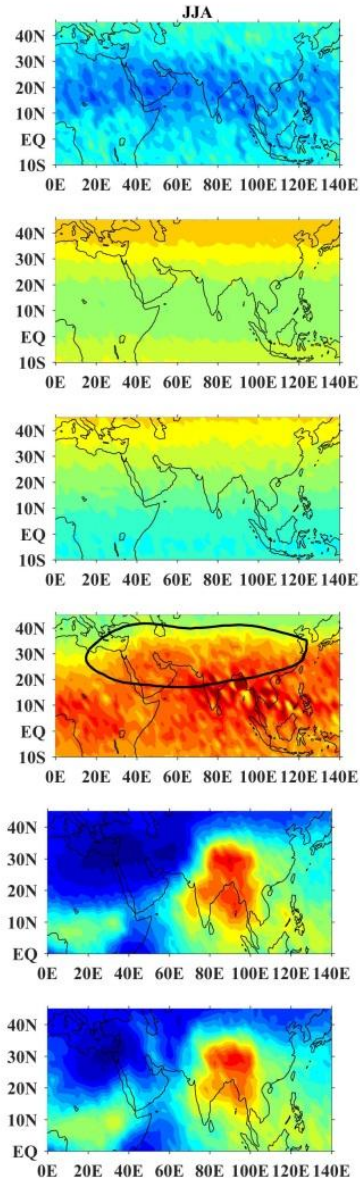
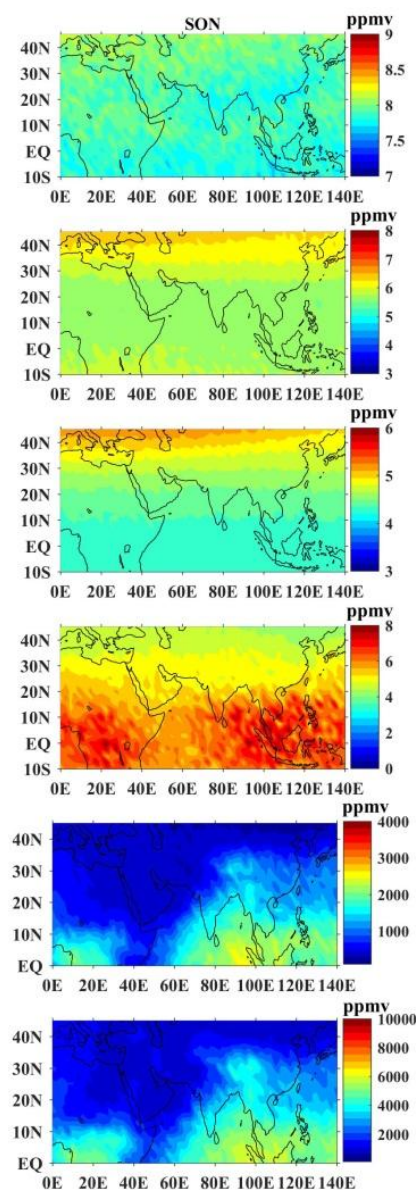
Figure 2. Diurnal variability of water vapour mixing ratio (WMR) for different seasons of Region-1 (R1), Region-2 (R2), and Region-3 (R3) (see text for region averaging). COSMIC derived water vapour is from 2-10 km, whereas SABER derived is from 15-65 km.
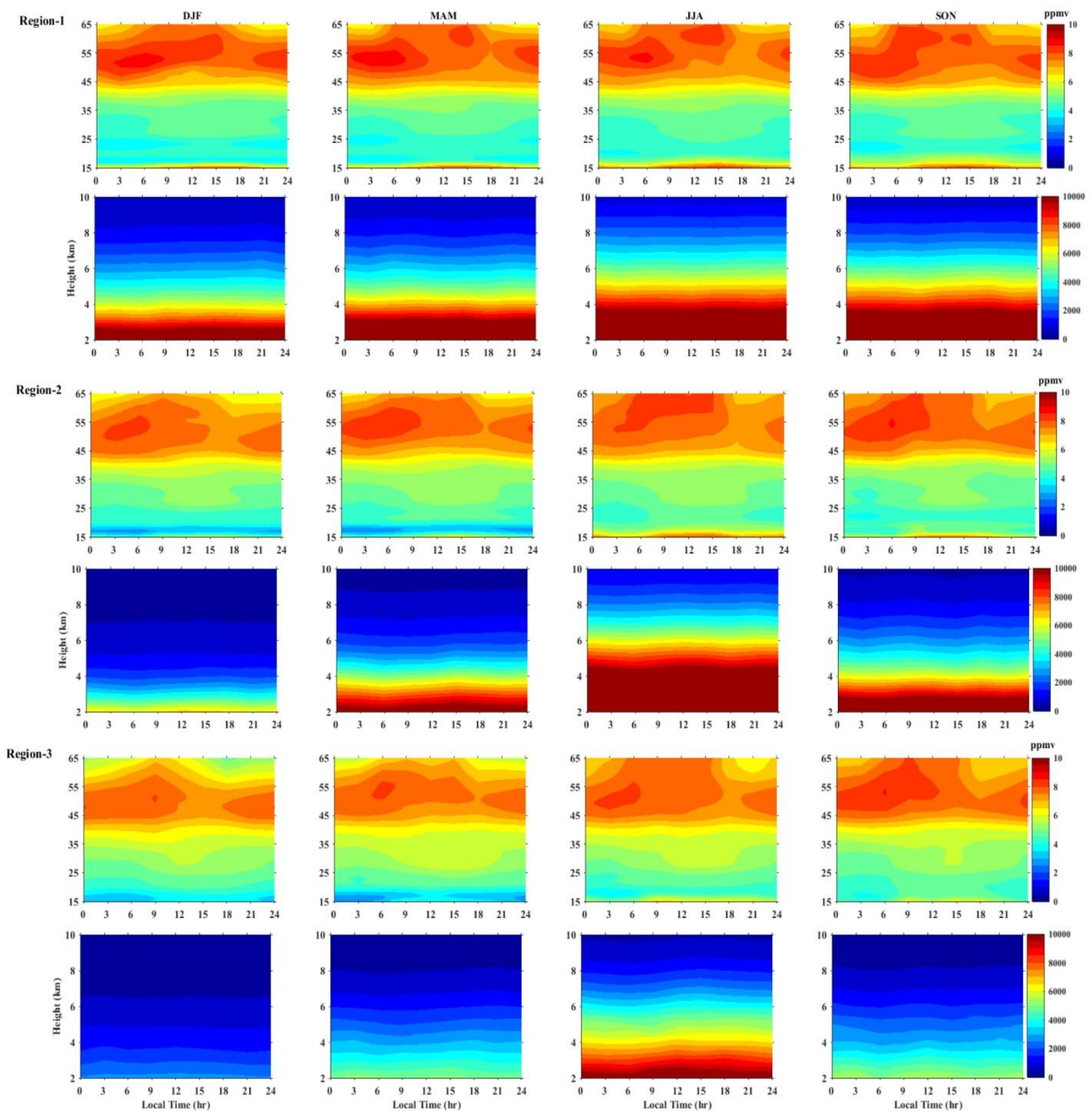
Figure 3. Same as Fig.2, but for diurnal mean removed.
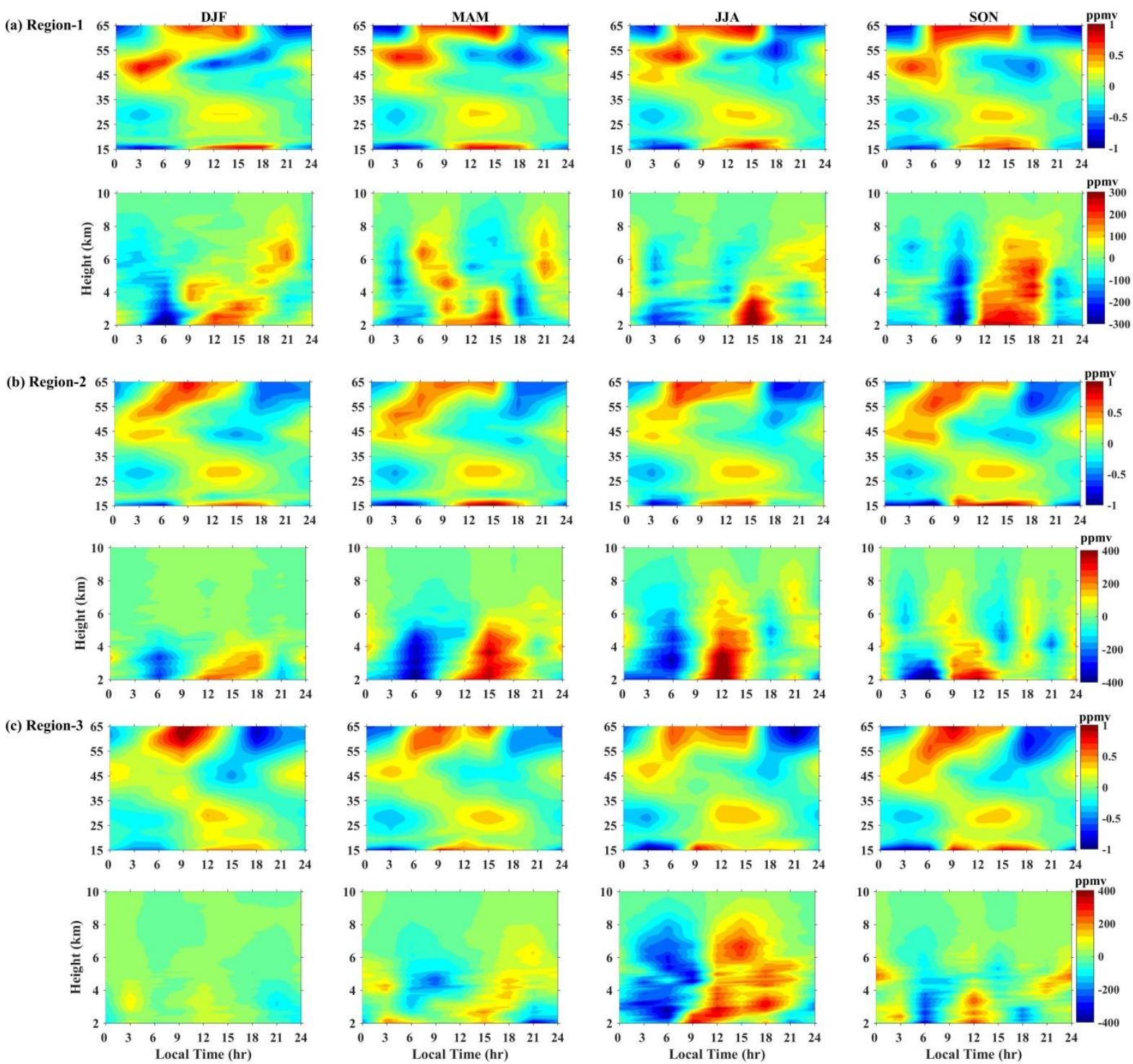
Figure 4. Diurnal variability of temperature (diurnal mean removed) for different seasons of Region-1 (R1), Region-2 (R2), and Region-3 (R3). COSMIC derived temperature is from 0-35 km, whereas SABER derived is from $15-65 \mathrm{~km}$.
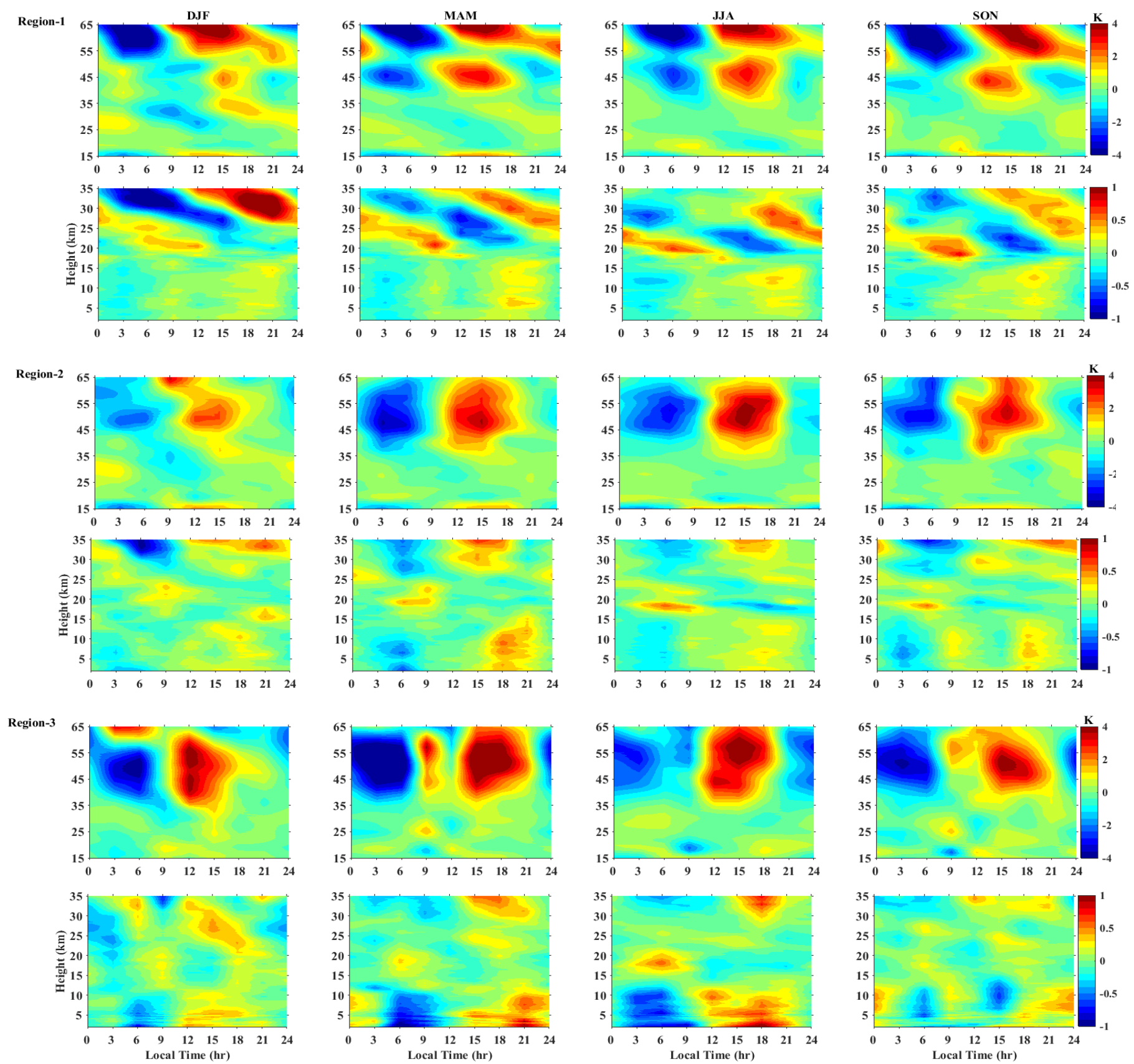
Figure 5. Diurnal variability of water vapour mixing ratio (WMR) (blue) and temperature (T) (red) at (a) 6 and (b) $8 \mathrm{~km}$ from COSMIC, and (c) 16, (d) 25, (e) 40 and (f) $50 \mathrm{~km}$ from SABER measurements for different seasons for Region-1 (R1), Region-2 (R2), and Region-3 (R3).

(a)
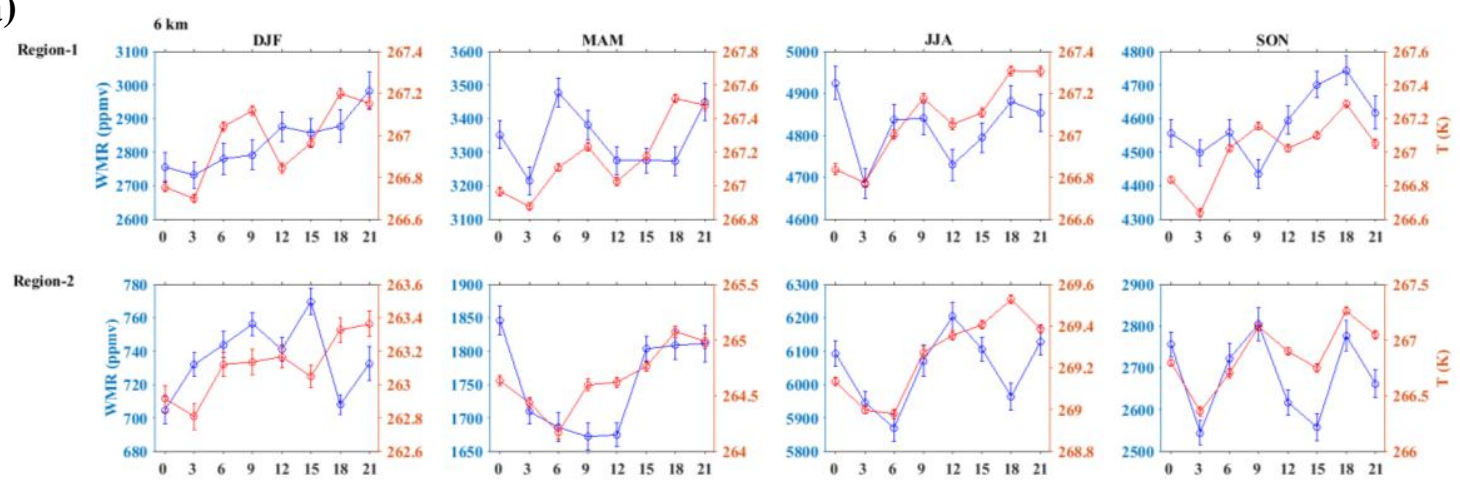

Region-3
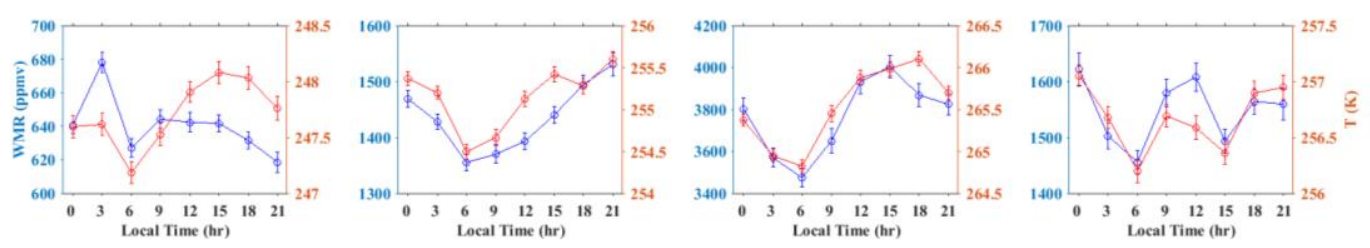

(b)
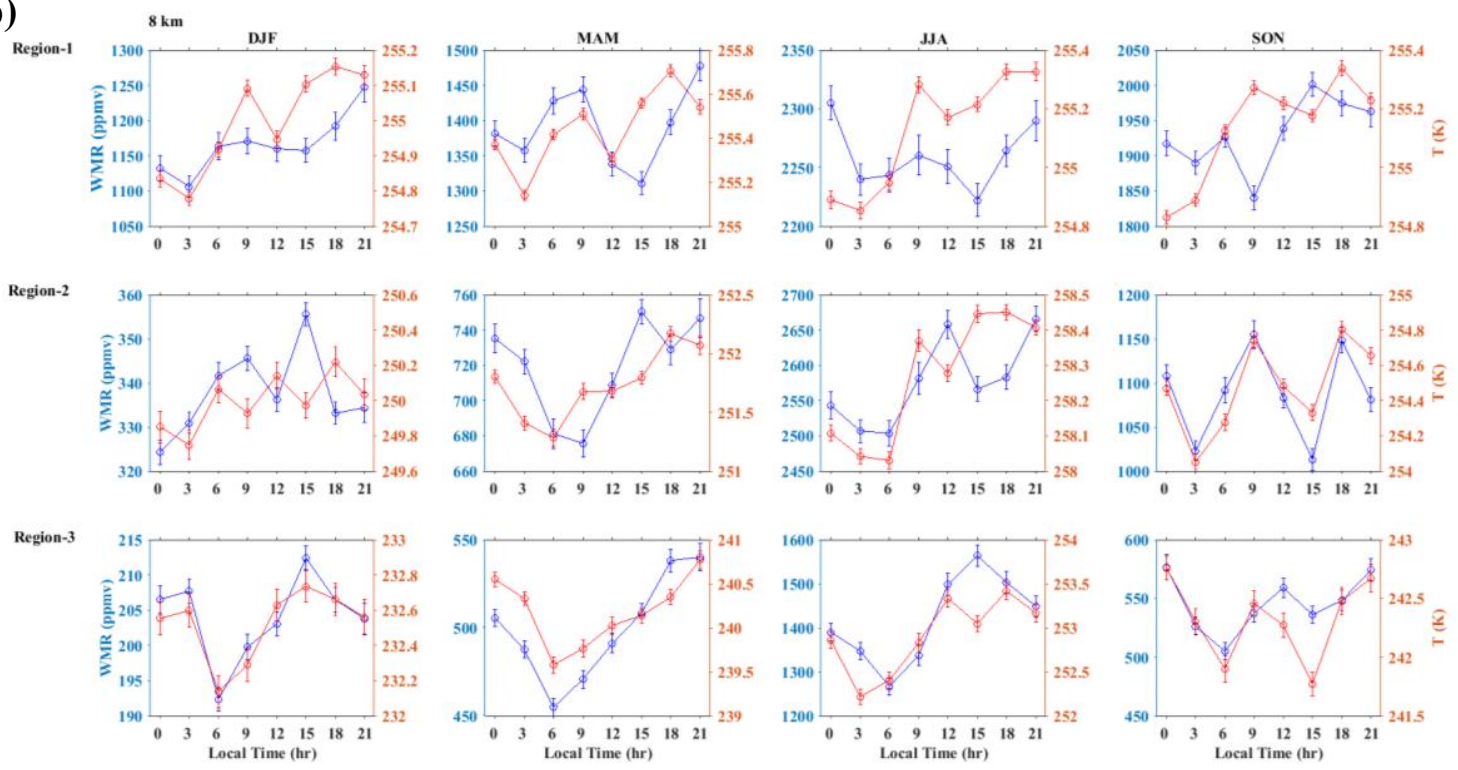
(c)

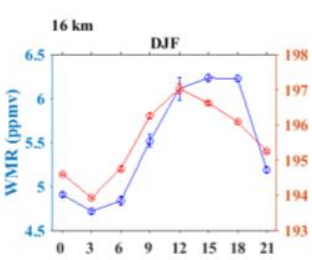

Region-2

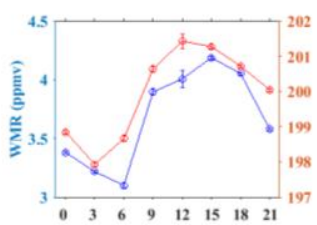

Region-3

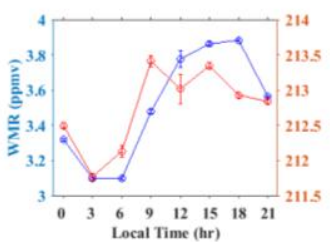

(d)

Region-1

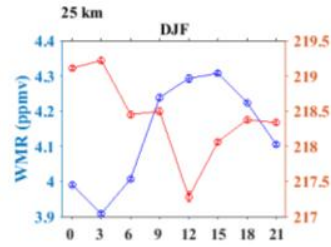

Region-2

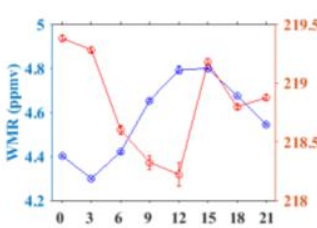

Region-3

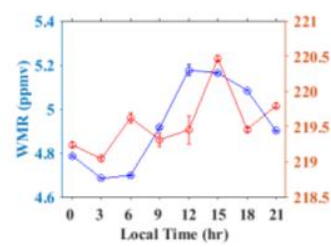

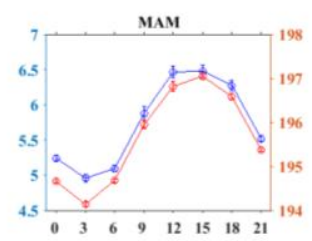
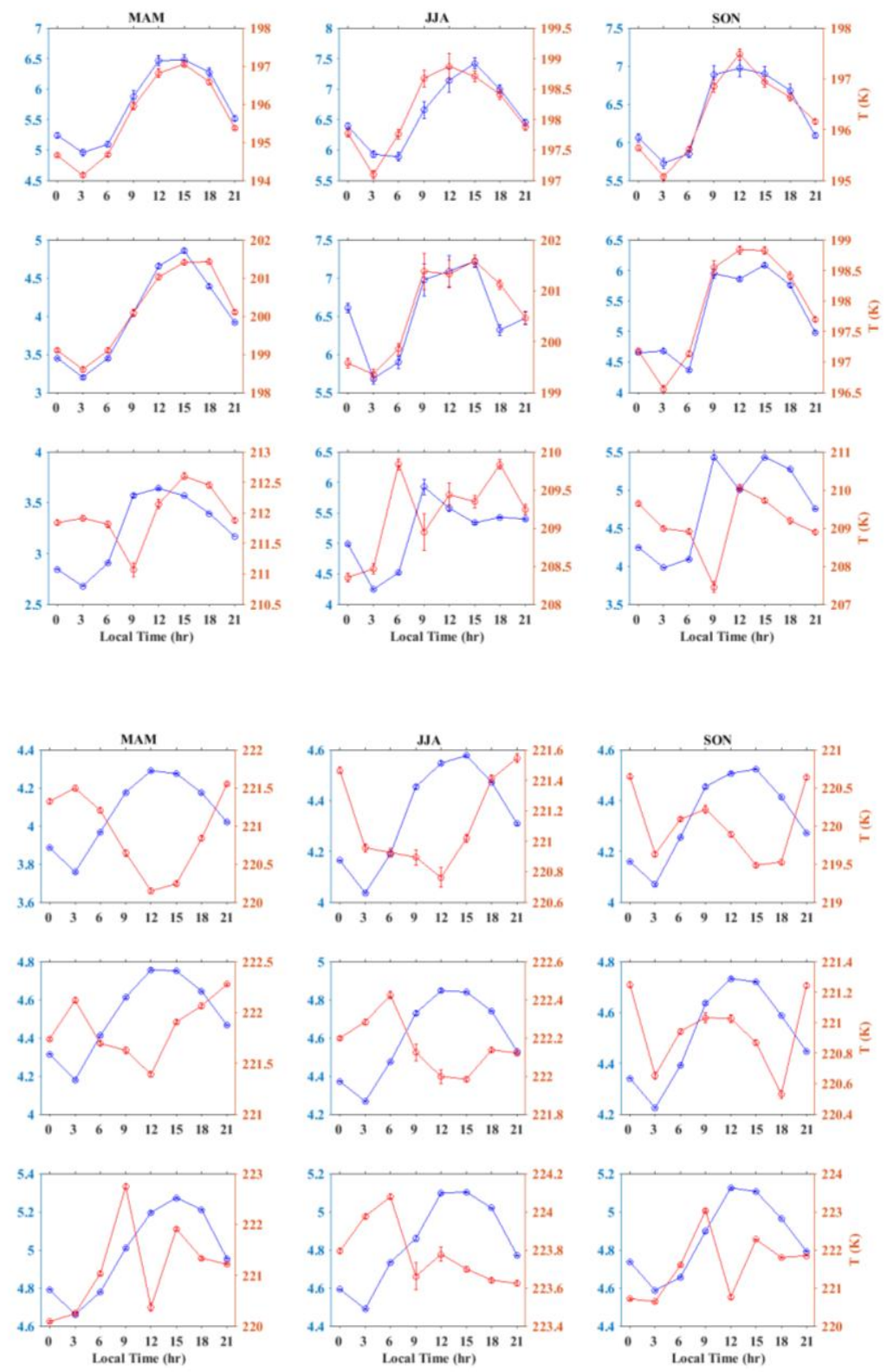
(e)
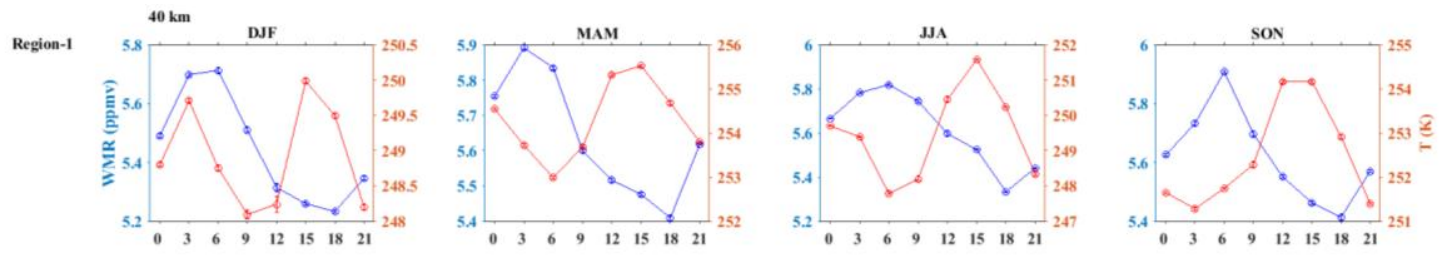

Region-2
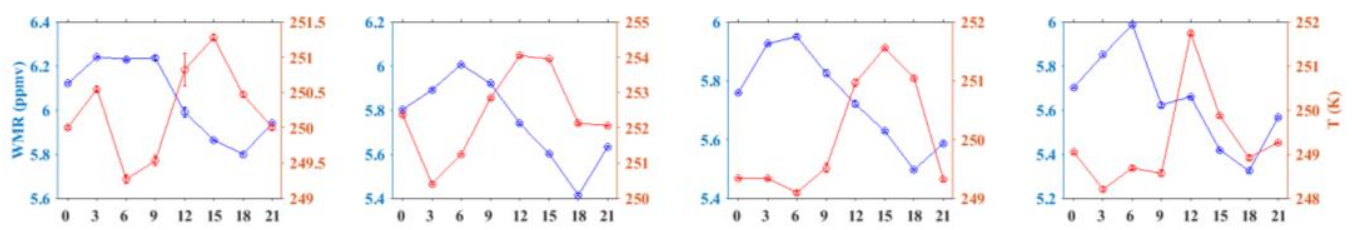

Region-3
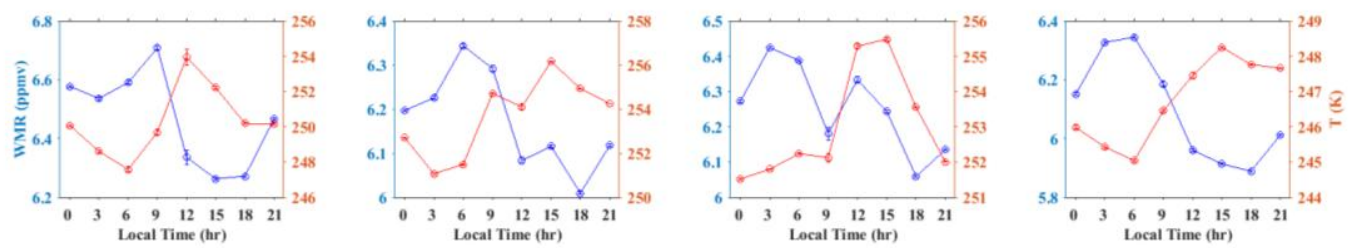

(f)
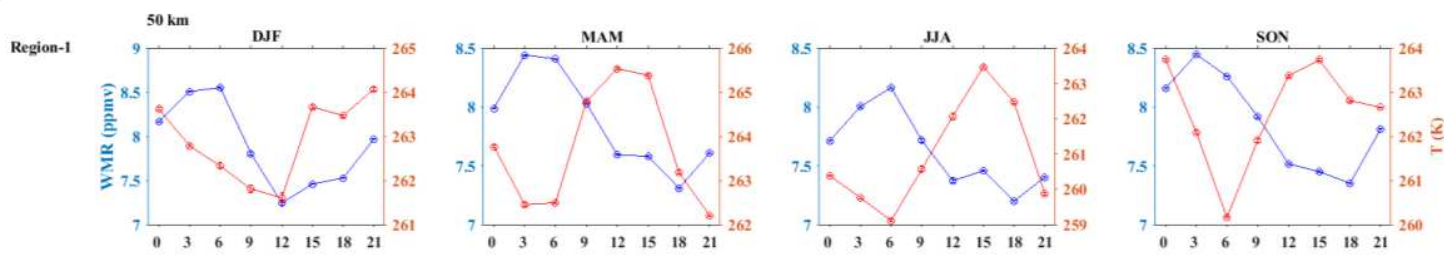

Region-2
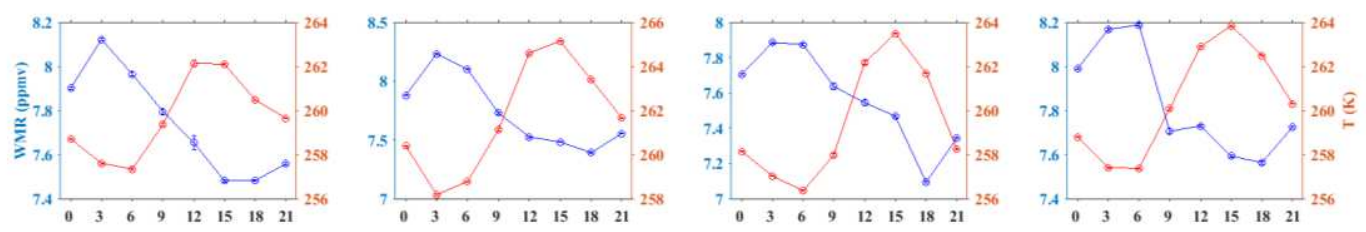

Region-3
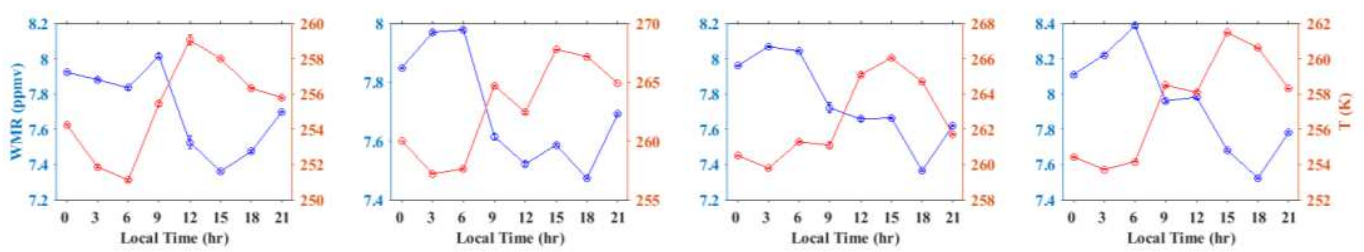
Figure 6. Diurnal variability of mean removed water vapour mixing ratio (WMR) (black) and saturation mixing ratio (SMR) (red) at 17-18 km derived from SABER, tropopause altitude (blue), tropopause temperature (magenta) derived from COSMIC temperature profiles for different seasons of Region-1 (R1), Region-2 (R2), and Region-3 (R3). Coldpoint tropopause altitude (CPT-A) and temperature (CPT-T) are estimated for Region-1 and -2, whereas lapse rate tropopause (LRT) is estimated for Region-3, as well-defined CPT cannot be obtained for Region-3, except for JJA. Vertical lines indicate the respective standard errors.
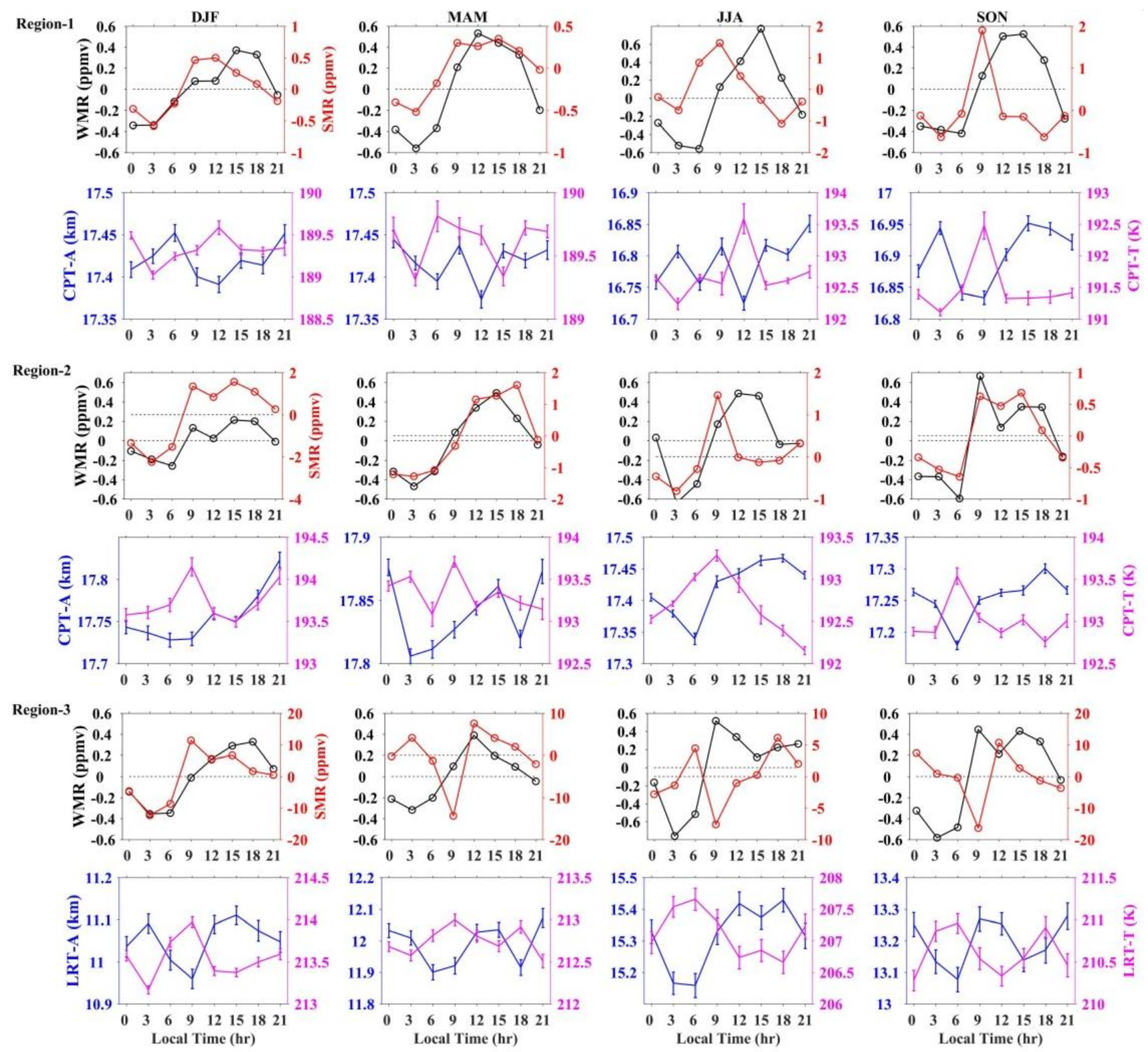
Figure 7. Height profiles of correlation coefficient ( $r$ ) between WMR and temperature (T) for different seasons of Region-1, Region-2, and Region-3. The profiles from 5-10 km (5-25 $\mathrm{km}$ ) are from COSMIC derived WMR (T), whereas the profile from $15-60 \mathrm{~km}$ is from SABER derived WMR and T.
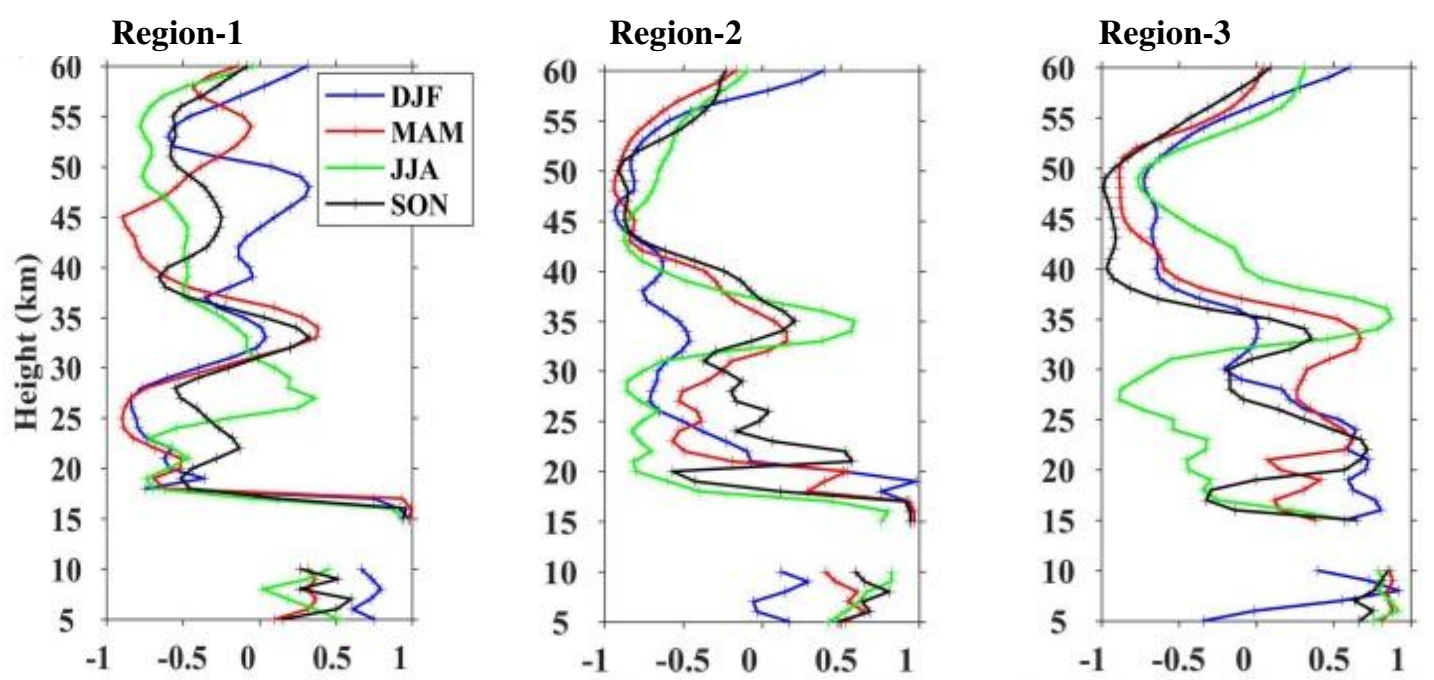

Corelation coefficient (WMR, T)

Corelation coefficient (WMR, T) Corelation coefficient (WMR, T) 
Figure 8. Height profiles of diurnal amplitude and phase of (a) WMR, and (b) temperature for different seasons at Region $-1,-2,-3$. The profiles from 5-10 km (5-25 km) are from COSMIC derived WMR (T), whereas the profile from 15-60 km is from SABER derived WMR and $\mathrm{T}$.
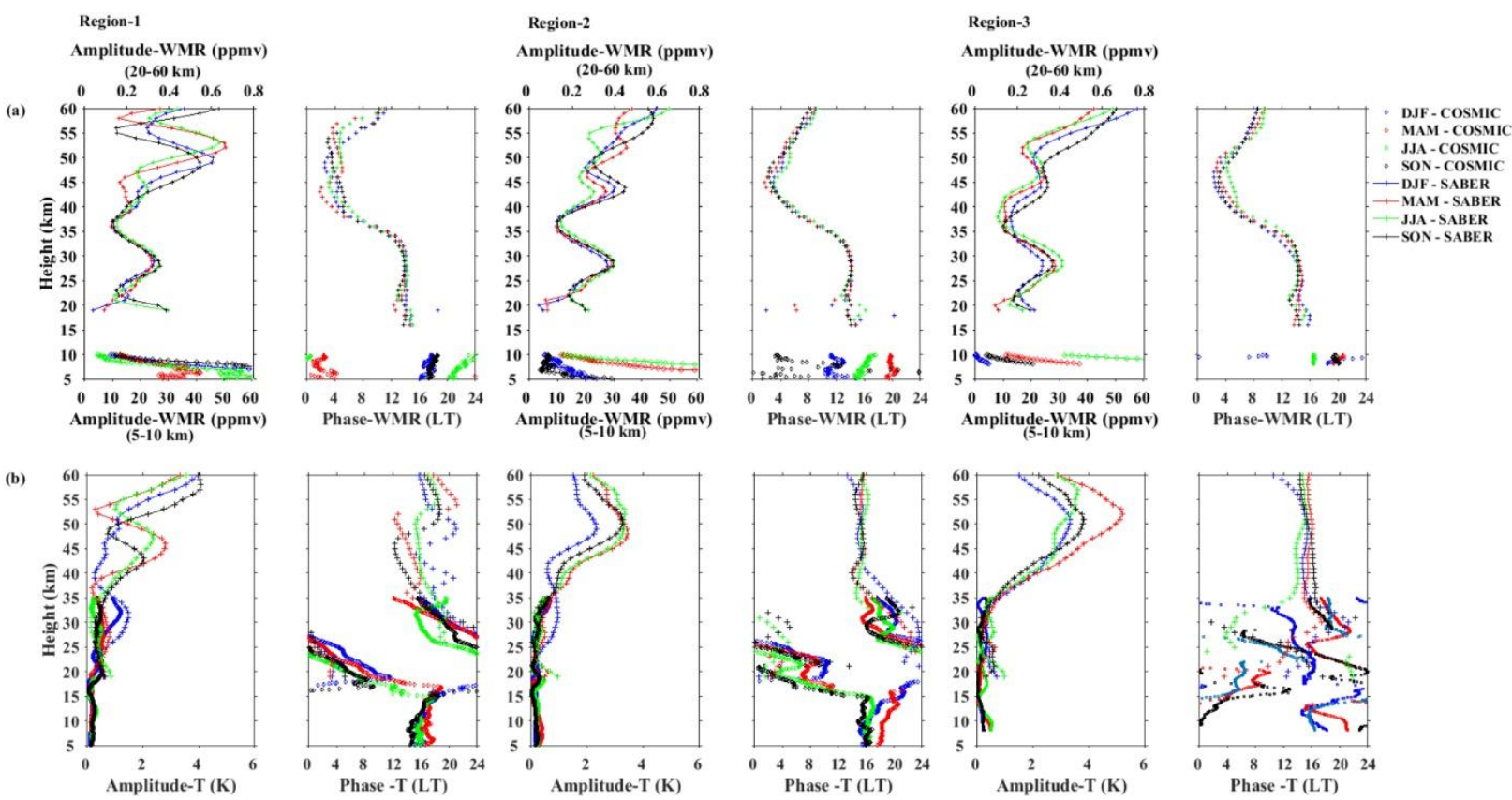
Figure S1. Temperature profiles (black) before (left) and after (right) quality control for January (2007-2019) between $0-10^{\circ} \mathrm{N}$ and $60-100^{\circ} \mathrm{E}$. Red and green lines in left panel indicate the $-3 \sigma$ and $+3 \sigma$, respectively for the month of January of same grid.
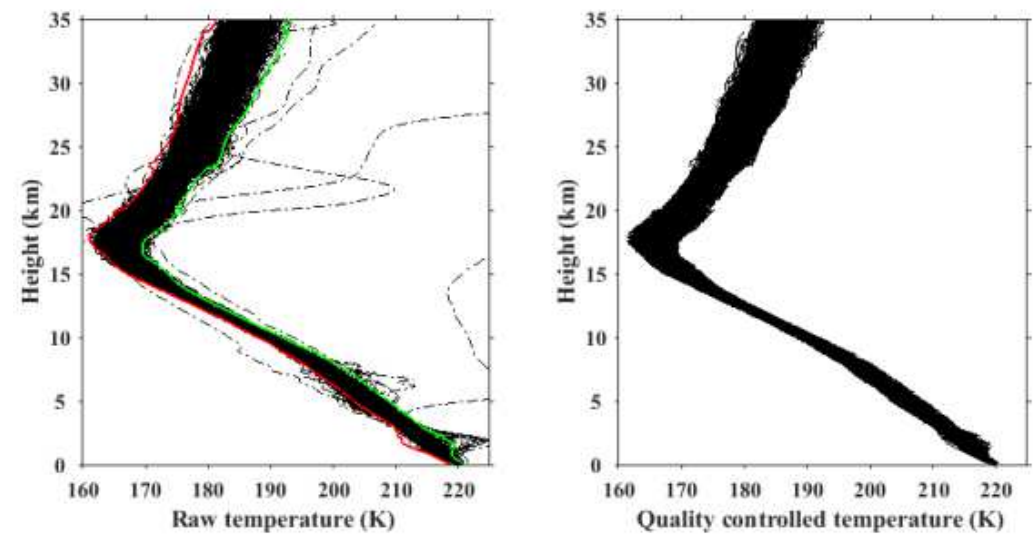

Figure S2. Water vapour mixing ratio (WMR) profiles (black) before (left) and after (right) quality control for January (2007-2019) between $0-10^{\circ} \mathrm{N}$ and $60-100^{\circ} \mathrm{E}$. Red and green lines in left panel indicate the 0.25 percentile and 99.75 percentile, respectively for the month of January of same grid.
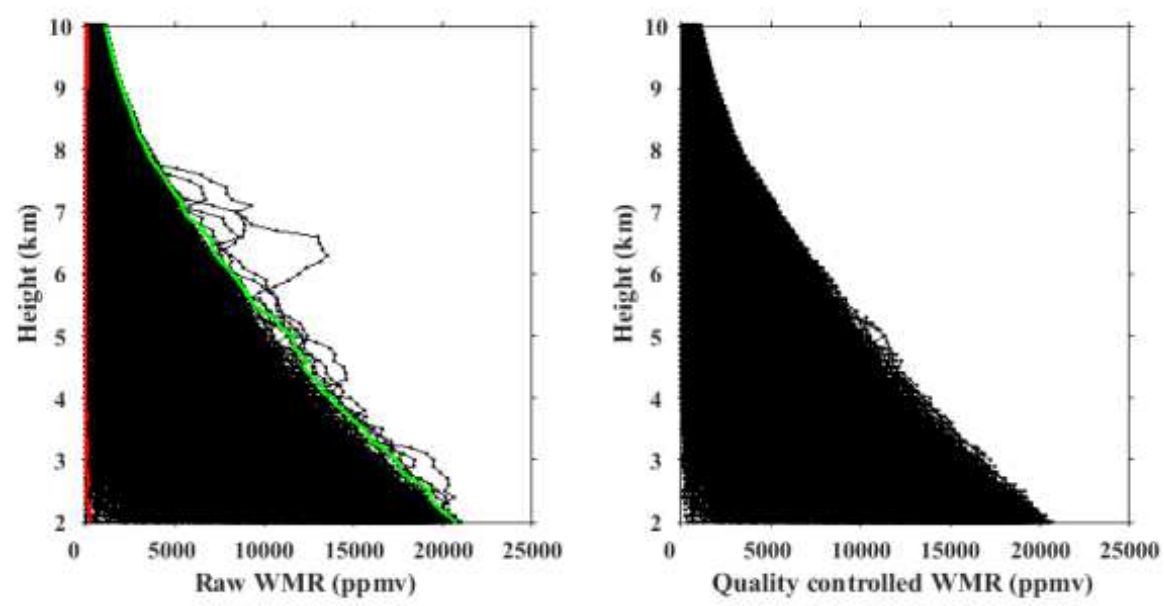
Figure S3. Same as Fig.2, but for standard errors (water vapour).
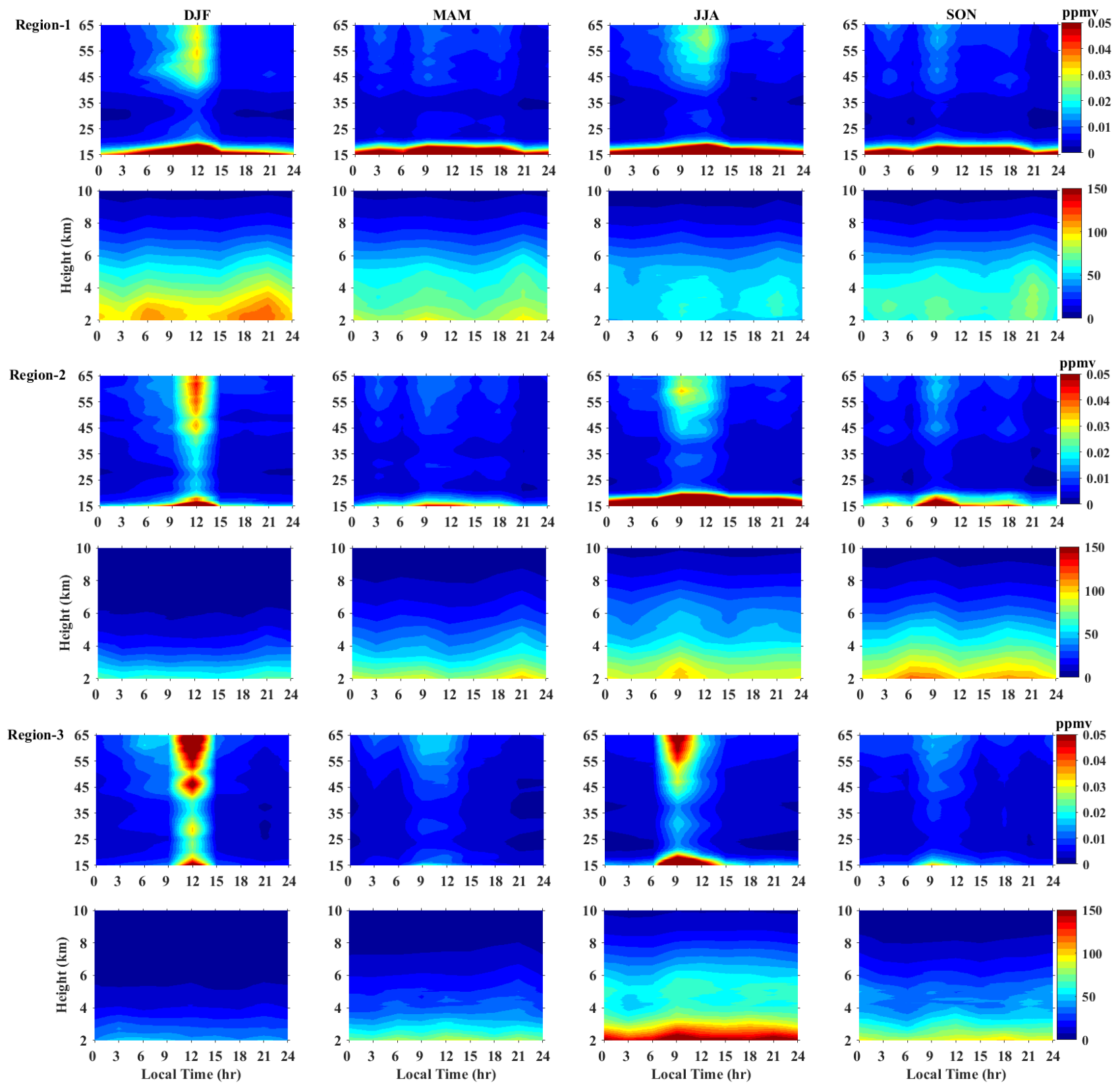
Figure S4. (left panels) Time-series of water vapour mixing ratio for different seasons at (a) 6 $\mathrm{km}$, (b) $8 \mathrm{~km}$, (c) $16 \mathrm{~km}$, (d) $25 \mathrm{~km}$, (d) $40 \mathrm{~km}$, and (e) $50 \mathrm{~km}$ along with its (right panels) standard error for Region-1 (R1), Region-2 (R2), and Region-3 (R3).
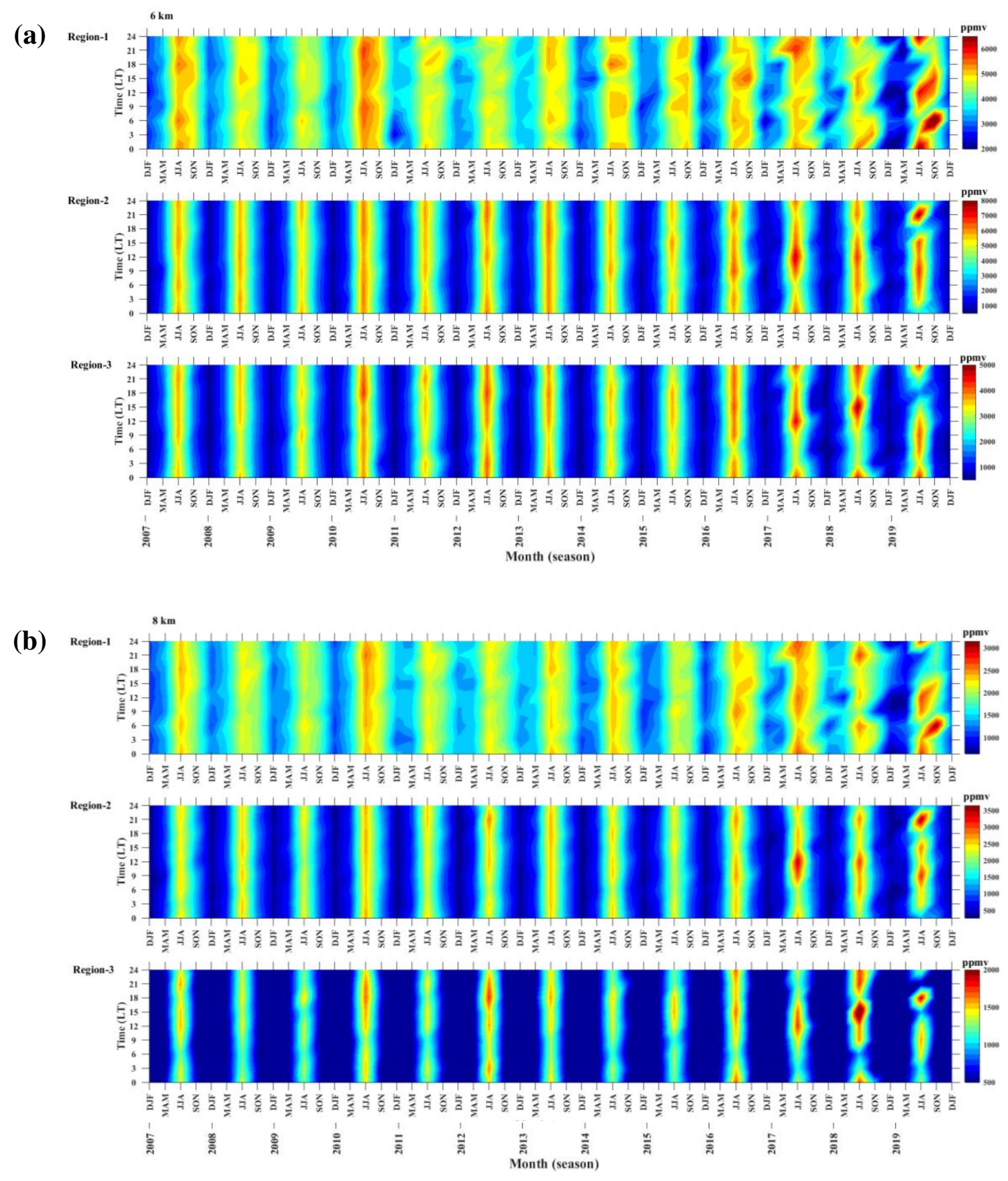
(c)
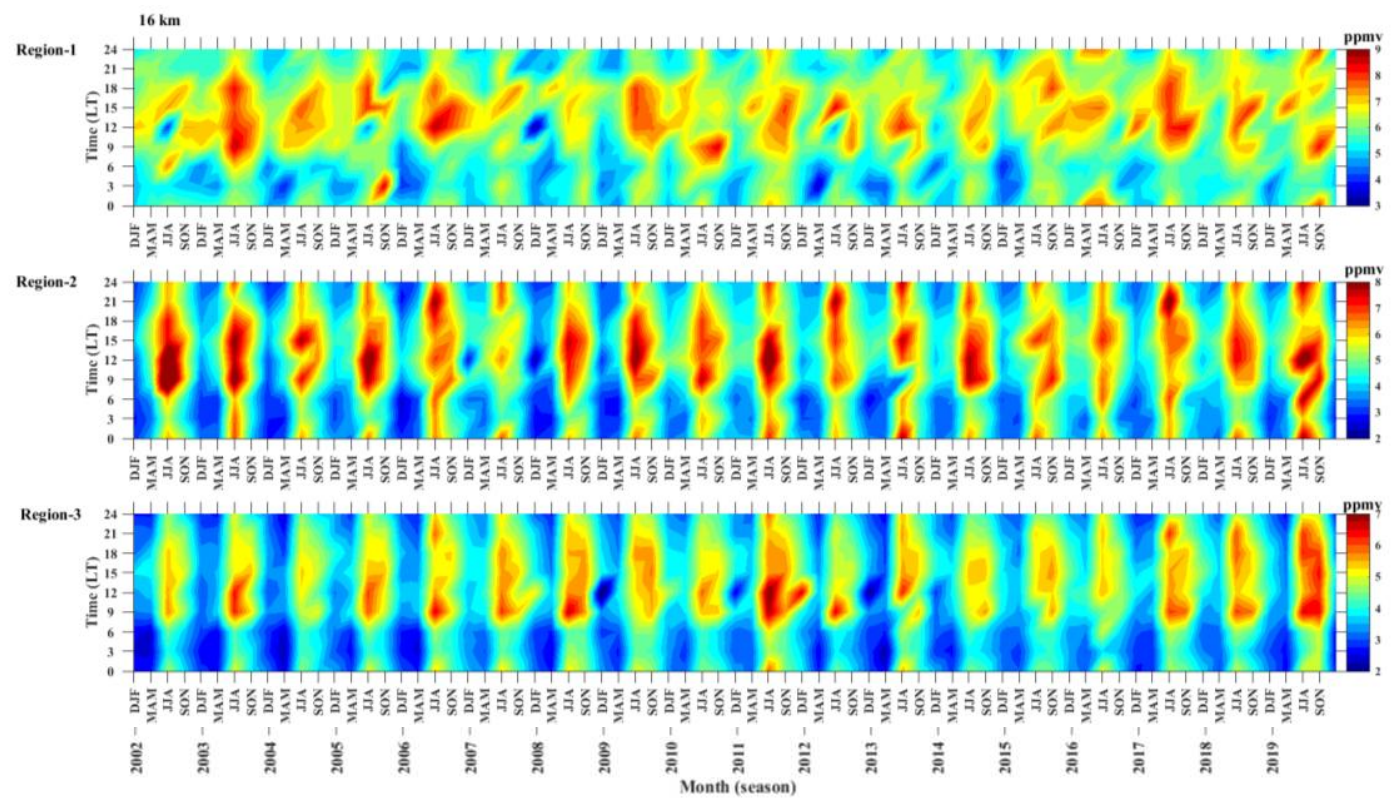

(d)
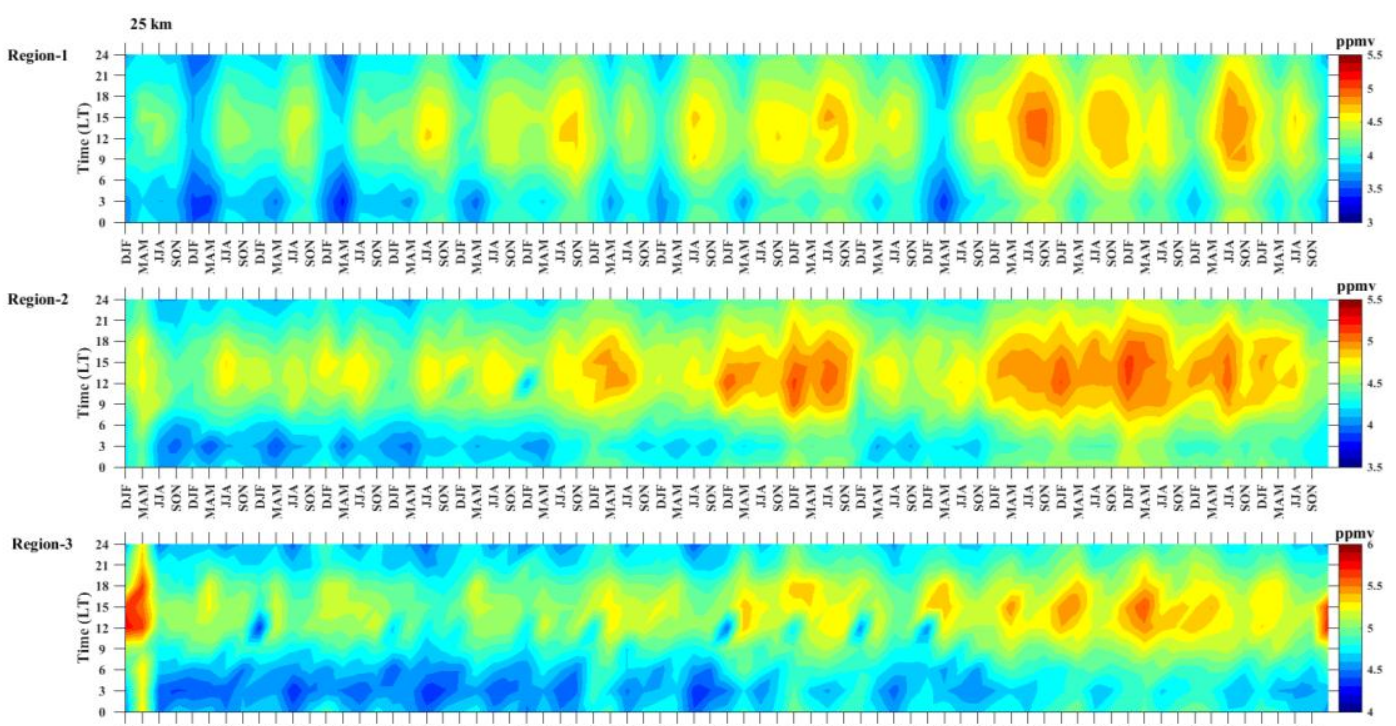

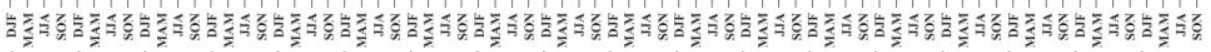

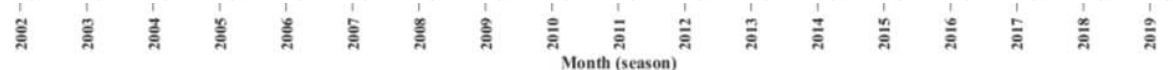


(n)

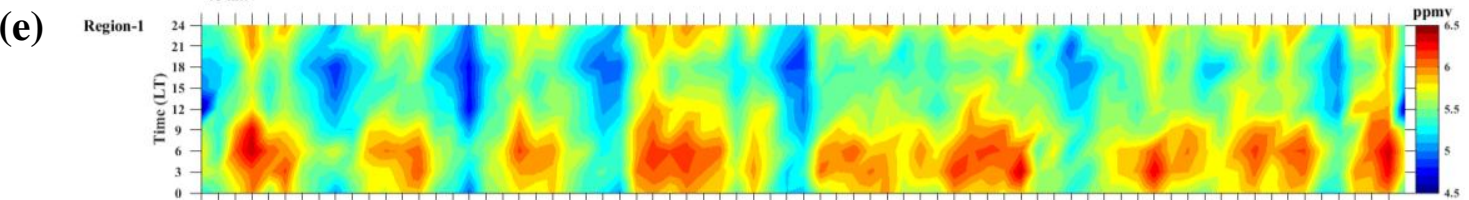

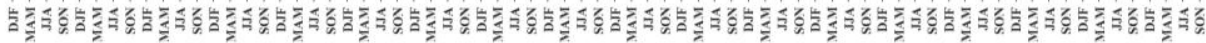
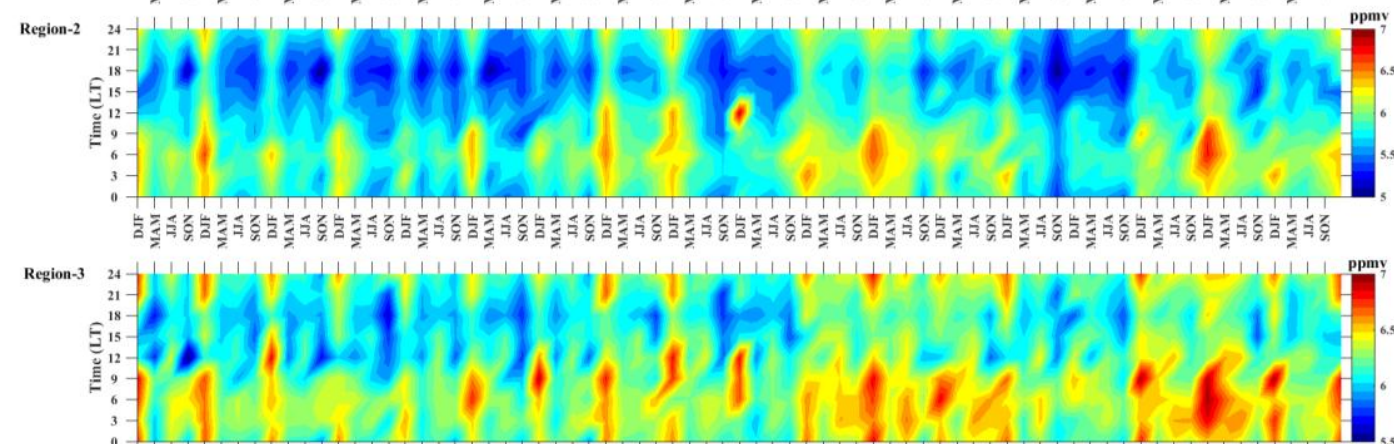

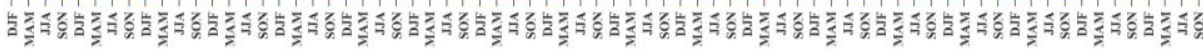

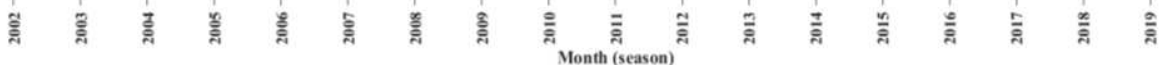

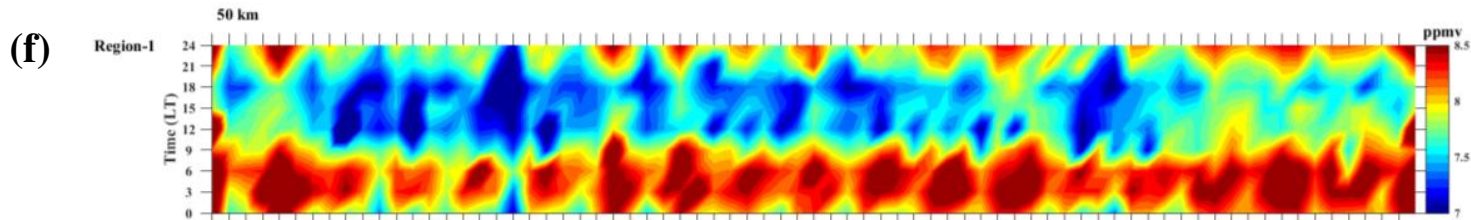

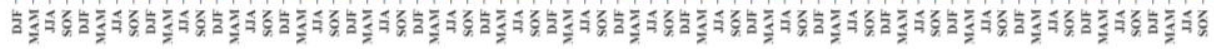
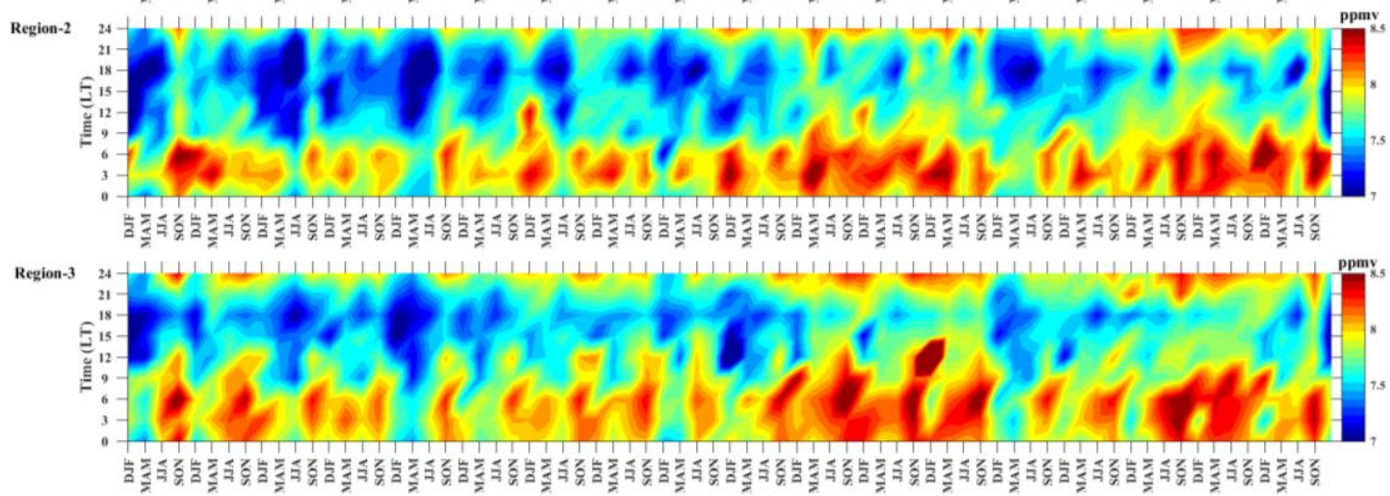

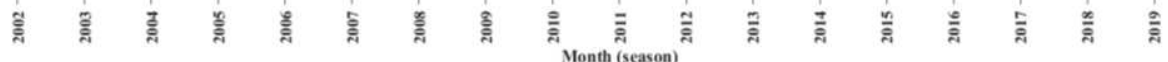


Figure S5. Same as Fig.4, but for standard error (temperature).
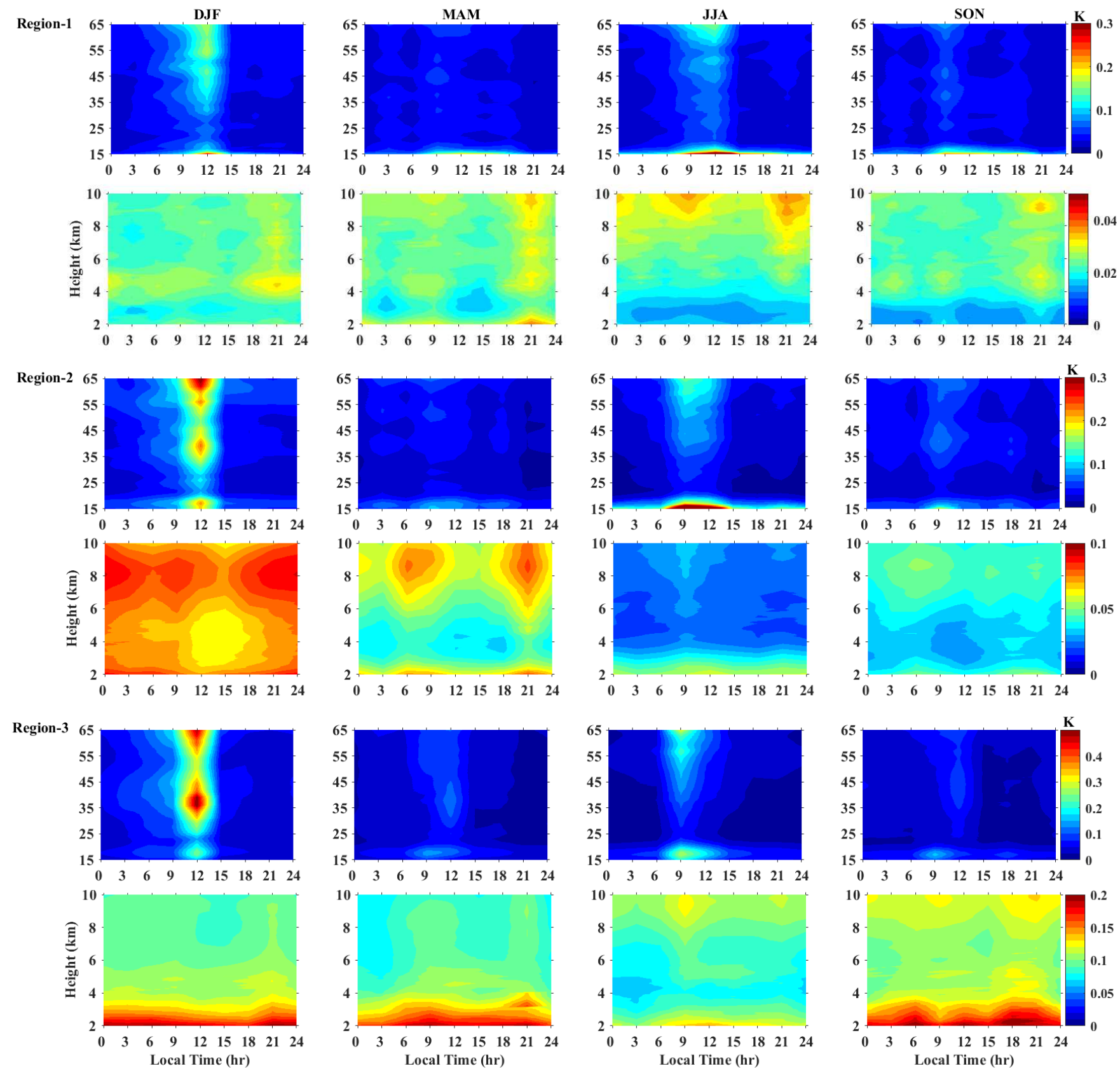